Original Research Paper

\title{
Machine Motion Equations Presented in a New General Format
}

\author{
${ }^{1}$ Nicolae Petrescu and ${ }^{2}$ Florian Ion Tiberiu Petrescu \\ ${ }^{\text {I} B u c h a r e s t ~ U n i v e r s i t y, ~ B u c h a r e s t, ~(C E), ~ R o m a n i a ~}$ \\ ${ }^{2}$ ARoTMM-IFToMM, Bucharest Polytechnic University, Bucharest, (CE), Romania
}

\section{Article history}

Received: 17-03-2019

Revised: 09-04-2019

Accepted: 21-05-2019

Corresponding Author: Florian Ion T. Petrescu ARoTMM-IFToMM, Bucharest Polytechnic University, Bucharest, (CE), Romania Email: fitpetrescu@gmail.com

\begin{abstract}
Considering the increased importance of robots nowadays, when no large factory or factory can work without robots, we want to present in the work the motion equations of the machine in an original form, both in terms of aspect and their deduction. The machine's motion equations can be used in dynamic calculations at any type of machine, whether it be a motor, a compressor, a lucrative machine, a robot, a system, a mechanism, a vehicle, a mechanical transmission, or any other type of car. The dynamics of systems is their real movement, the dynamic movement, in which the influences of three main factors interfere, which modify the kinematics of the mechanism when it moves really, dynamic. The first dynamic factor is the forces of inertia or the effect of inertial masses. The second important dynamic factor is that of the couplings, of the linkages within the respective machine mechanisms. The latter and the third dynamic factor represents the influence of system elasticity on its dynamic functioning. Only dynamic coefficient of inertia and the influence of kinematic couplings in the system were used in the analyzed sample. The dynamic coefficient due to elasticity and deformation in the system has not been taken into account since the overwhelming influence of the inertial forces is impacted by additional dynamic changes and also by the kinematic couplings in the system and the elastic deformations do not greatly influence the dynamics of the system in the case of the example remembered. If a robot was being discussed, things were similar, as in the case of various vehicles and various mechanisms and machines. However, for rigid memory transmissions, elastic deformations are important, which is why they should be considered in such systems.
\end{abstract}

Keywords: Robots, Mechatronic Systems, Structure, Dynamics, Dynamics Systems, Machines, Machine Motion Equations, Dynamic Factors

\section{Introduction}

Today, robots are increasingly present in the machine building industry, sometimes even in some sections, to replace workers altogether due to the high quality of their work, repetitive, without stopping or interrupting, without manufacturing and assembly.

In addition, robots do not get sick, do not need medical leave or rest, work faster and better than people and support dyers, general assemblies, etc.

Generally, robots have increased the quality and productivity of work and have not even created a union to defend their claims, demanding higher wages for them and larger holidays.
Interestingly, a robot works without pause, but unpaid, without breaks, without complaining about factory conditions.

Robots can work on three shifts, that is, permanently, but not by moving them as humans, but they always remain the same robots deployed on a day without interruptions, without pauses, without rest, without problems.

Robots are today highly valued by major carmakers which even build complete sections where only robots work because they do not have a trade union, they do not require increased salaries (they actually work without any salary), they do not have to leave on holidays, do not want free days and can even work on Saturdays and Sundays, without breaks, if necessary, on three exchanges, 
including in toxic, dangerous environments, or even in hard-to-reach areas. The importance of implementing robots can no longer be challenged. They have increased the quality of work and the production of an enterprise so that they can no longer give up their help.

Workers reclassified and worked only in more friendly jobs or other jobs, such as supermarkets, in better conditions, with higher wages, more days off and are satisfied with the production and sales gains due to robot work in large factories.

One can clearly state that our robots have considerably improved our lives. Thanks to them, a new free day for almost all working people was introduced on Friday, in addition to Saturday and we will soon be able to enter another free day, but we have to choose Monday or Thursday.

People were initially trained by trade union leaders to track and sabotage robots, destroy them and not accept them. Today things are clear and the robots work quietly in the big companies and factories for the good of all, so now we can accept the silence of automation, robotics, electronics, without letting us be fooled by the trade union leaders who slowly slow down and calm down.

Whether we like it or not, the robots have already stolen all their heavy jobs.

Certain anthropomorphic robots are, as we have already said, in most of the most widespread and widely used works around the world, due to their ability to adapt quickly to forced labor, working without breaks or 24 hours, air or salary. Anthropomorphic robots are thin, elegant, easy to configure and adapted to virtually any location, being the most flexible, useful, more penetrating, easier to install and maintain. For the first time, these robots affirmed themselves in the automotive industry and especially in the automotive industry, today they have penetrated almost all industrial fields, being easily adaptable, flexible, dynamic, resilient, cheaper than other models, occupying a workspace important. They can also work in toxic or hazardous environments used in dyeing, chemical cleaning, chemical or nuclear environments, dealing with explosive objects or military missions in land or sea mines, even if they are forbidden to use them. countries around the world that use them, such as Afghanistan.

The most used industrial robots today are built. The importance of studying anthropomorphic robots has also been signaled, being today the most widespread robots around the world, thanks to its simple design, construction, implementation, operation and maintenance. In addition, anthropomorphic systems are simpler and cheaper from a technological point of view, with consistent, demanding and repetitive work, with no major maintenance problems.

Considering the increased importance of robots nowadays, when no large factory or factory can work without robots, one wants to present in the work the motion equations of the machine in an original form, both in terms of aspect and their deduction. The machine's motion equations can be used in dynamic calculations at any type of machine, whether it be a motor, a compressor, a lucrative machine, a robot, a system, a mechanism, a vehicle, a mechanical transmission, or any other type of car. The dynamics of systems is their real movement, the dynamic movement, in which the influences of three main factors interfere, which modify the kinematics of the mechanism when it moves really, dynamic. The first dynamic factor is the forces of inertia or the effect of inertial masses. The second important dynamic factor is that of the couplings, of the linkages within the respective machine mechanisms. The latter and the third dynamic factor represents the influence of system elasticity on its dynamic functioning (Antonescu and Petrescu, 1985; 1989; Antonescu et al., 1985a; 1985b; 1986; 1987; 1988; 1994; 1997; 2000a; 2000b; 2001; Aversa et al., 2017a; $2017 \mathrm{~b}$; 2017c; 2017d; 2017e; 2016a; 2016b; 2016c; 2016d; 2016e; 2016f; 2016g; 2016h; 2016i; 2016j; 2016k; 20161; 2016m; 2016n; 2016o; Cao et al., 2013; Dong et al., 2013; Comanescu, 2010; Franklin, 1930; He et al., 2013; Lee, 2013; Lin et al., 2013; Liu et al., 2013; Padula and Perdereau, 2013; Perumaal and Jawahar, 2013; Petrescu, 2011; 2015a; 2015b; Petrescu and Petrescu, 1995a; 1995b; 1997a; 1997b; 1997c; $2000 \mathrm{a} ; 2000 \mathrm{~b} ; 2002 \mathrm{a} ; 2002 \mathrm{~b} ; 2003$; 2005a; 2005b; $2005 \mathrm{c} ; 2005 \mathrm{~d} ; 2005 \mathrm{e} ; 2011 \mathrm{a} ; 2011 \mathrm{~b} ; 2012 \mathrm{a} ; 2012 \mathrm{~b}$; 2013a; 2013b; 2013c; 2013d; 2013e; 2016a; 2016b; 2016c; Petrescu et al., 2009; 2016; 2017a; 2017b; 2017c; $2017 \mathrm{~d} ; 2017 \mathrm{e} ; 2017 \mathrm{f} ; 2017 \mathrm{~g} ; 2017 \mathrm{~h} ; 2017 \mathrm{i} ; 2017 \mathrm{j}$; $2017 \mathrm{k} ; 2017 \mathrm{l} ; 2017 \mathrm{~m} ; 2017 \mathrm{n} ; 2017 \mathrm{o} ; 2017 \mathrm{p} ; 2017 \mathrm{q}$; $2017 \mathrm{r} ; 2017 \mathrm{~s} ; 2017 \mathrm{t} ; 2017 \mathrm{u} ; 2017 \mathrm{v} ; 2017 \mathrm{w} ; 2017 \mathrm{x}$; 2017y; 2017z; 2017aa; 2017ab; 2017ac; 2017ad; 2017ae; 2018a; 2018b; 2018c; 2018d; 2018e; 2018f; 2018g; 2018h; 2018i; 2018j; 2018k; 20181; 2018m; 2018n).

\section{Materials and Methods}

The angular velocity of the driving element $\omega^{*}$ is considered to be constant because it is given by a motor that generally operates in a constant mode with a constant angular velocity $\omega_{n}$, which is considered the input speed in the system. However, due to the dynamic influences given by the whole system, the angular velocity of the driving element $\omega^{*}$ permanently undergoes changes of value, dynamic changes depending on the position occupied by the leading element at that time. One can, therefore, consider that the angular velocity of the leading element is a function of the $\varphi$ input angle. Dynamically, variable input angular velocity $\omega^{*}$ is a function of constant input speed $\omega_{n}$ and three essential dynamic factors $D_{i}, D_{c}, D_{e}$ (relationship 1, which is the first original machine motion equation): 


$$
\omega^{*}=\omega_{n} \cdot D_{i} \cdot D_{c} \cdot D_{e}
$$

If it gets up to the square one obtains the form (2), which by derivation generates the equation of the angular acceleration (3), which is the second original machine motion equation.

$\omega^{* 2}=\omega_{n}^{2} \cdot D_{i}^{2} \cdot D_{c}^{2} \cdot D_{e}^{2}$

$\left\{\begin{array}{l}\varepsilon^{*}=\omega_{n}^{2} \cdot\left(D_{i} \cdot D_{i}^{\prime} \cdot D_{c}^{2} \cdot D_{e}^{2}\right. \\ \left.+D_{i}^{2} \cdot D_{e}^{2} \cdot D_{c} \cdot D_{c}^{\prime}+D_{i}^{2} \cdot D_{c}^{2} \cdot D_{e} \cdot D_{e}^{\prime}\right)\end{array}\right.$

The three main dynamic coefficients represent the dynamic coefficient of the inertial forces of the whole system $D_{i}$, the coefficient of forces imposed by the system couplings $D_{c}$ and the coefficient of the elastic deformations in the system $D_{e}$. If want to eliminate the influence of one of the three coefficients, it is enough to equate that coefficient with the value of 1 .

The inertial coefficient (the most important) is given by the relationships from the system (4), (Petrescu, 2015b):

$$
\left\{\begin{array}{l}
D_{i}=\sqrt{\frac{J_{m}^{*}}{J^{*}} ;} D_{i}^{2}=\frac{J_{m}^{*}}{J^{*}} ; \\
D_{i} \cdot D_{i}^{\prime}=-\frac{1}{2} \frac{J_{m}^{*} \cdot J^{* \prime}}{J^{* 2}} \Rightarrow D_{i}^{\prime}=-\frac{1}{2} \frac{J_{m}^{*} \cdot J^{* \prime}}{D_{i} \cdot J^{* 2}}
\end{array}\right.
$$

where, $J^{*}$ is the mass inertia moment of the system and $J_{m}{ }^{*}$ represents its average value. The derivatives used (denoted by ') are those based on the angle $\varphi$.

$D_{c}$ and $D_{e}$ are variable depending on the dynamic system in question. $D_{c}$ can have a considerable influence, whereas $D_{e}$ it is generally of minor importance and can be disregarded by theory by its matching to the value 1 . The method is original and has a general character.

\section{Results}

An example of calculation is applied to internal combustion engines (Fig. 1; Petrescu, 2015b), where the dynamic inertial coefficient has the values given by systems relations (5-6), (system 5 when the mechanism works as a complessor and the system 6 when the mechanism works as a motor):

$$
\left\{\begin{array}{l}
D_{c}=\sin ^{2} \psi \\
\dot{D}_{c}=\sin 2 \psi \cdot \dot{\psi} \\
D_{c}^{\prime}=\sin 2 \psi \cdot \psi^{\prime} \\
\psi^{\prime}=\frac{\dot{\psi}}{\omega}
\end{array}\right.
$$

$$
\left\{\begin{array}{l}
D_{c}=\sin ^{2}(\psi-\phi) \\
\dot{D}_{c}=\sin 2(\psi-\phi) \cdot(\dot{\psi}-\omega) \\
D_{c}^{\prime}=\sin [2(\psi-\phi)] \cdot\left(\psi^{\prime}-1\right)
\end{array}\right.
$$

To determine dynamics at an Otto engine must (first at all) to set the formula of reduced moment of inertia (7); Fig. 1 (it takes $a_{1}=0$, as the crank is already balanced):

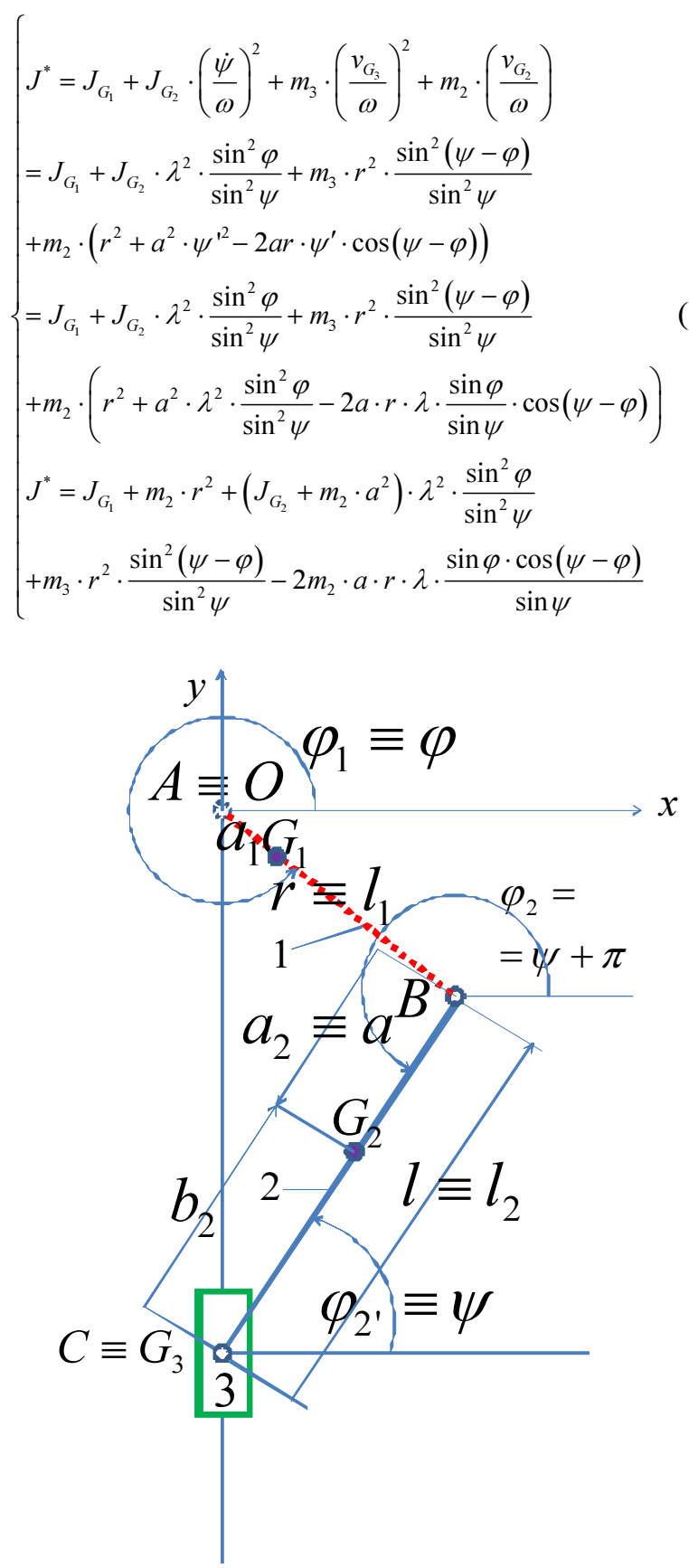

Fig. 1: The geometry of an Otto engine mechanism 
One determines:

$$
J_{M a x}^{*}, J_{\min }^{*}, J_{\text {med }}^{*} \equiv J_{m}^{*}=\frac{J_{M a x}^{*}+J_{\min }^{*}}{2}
$$

and $J^{* \prime}$, with relations $(8,9)$ :

$$
\left\{\begin{array}{l}
J^{* \prime}=\frac{1}{\sin ^{4} \psi} \cdot\left\{\left(J_{G_{2}}+m_{2} \cdot a^{2}\right) \cdot \lambda^{2}\right. \\
\cdot\left(\sin 2 \varphi \cdot \sin ^{2} \psi-2 \lambda \cdot \sin ^{3} \varphi \cdot \cos \psi\right) \\
+m_{3} \cdot r^{2} \cdot\left[\sin 2(\psi-\varphi) \cdot\left(\lambda \sin \varphi \cdot \sin \psi-\sin ^{2} \psi\right)\right. \\
\left.-2 \lambda \cdot \sin ^{2}(\psi-\varphi) \cdot \cos \psi \cdot \sin \varphi\right] \\
+2 m_{2} a r \lambda \cdot[\sin \varphi \cdot \sin \psi \cdot \sin (\psi-\varphi) \\
\cdot\left(\lambda \sin \varphi \cdot \sin \psi-\sin ^{2} \psi\right) \\
+\lambda \cdot \sin ^{2} \varphi \cdot \sin \psi \cdot \cos (\psi-\phi) \cdot \cos \psi \\
\left.\left.-\sin ^{3} \psi \cdot \cos \varphi \cdot \cos (\psi-\varphi)\right]\right\}
\end{array}\right.
$$

Method is applied separately for two distinct situations: When the engine is working on a compressor and into the motor system. Calculations should be made for an engine with a single cylinder.

\section{Dynamic Kinematics Analysis for the Otto Engine} in Compressor System

Now, one can see the engine main mechanism in compressor system (when the motor mechanism is acting from the crank). It is determining now, the velocities and the accelerations of the piston and motor shaft, normal and dynamic (Fig. 2-5).

\section{Dynamic Kinematics Analysis for the Otto Engine in Motor System}

Now, one can see the engine main mechanism in motor system (when the motor mechanism is acting from the piston). It is determining now, the velocities and the accelerations of the piston and motor shaft, normal and dynamic (Fig. 6-9).

\section{Dynamic Kinematics Analysis for an Otto Engine, Mono-cylinder}

Now, one can see the engine main mechanism in motor and compressor system (when the motor mechanism is acting from the piston and from the crank). It is determining now, the velocities and the accelerations of the piston and motor shaft, normal and dynamic (Fig. 10-14).

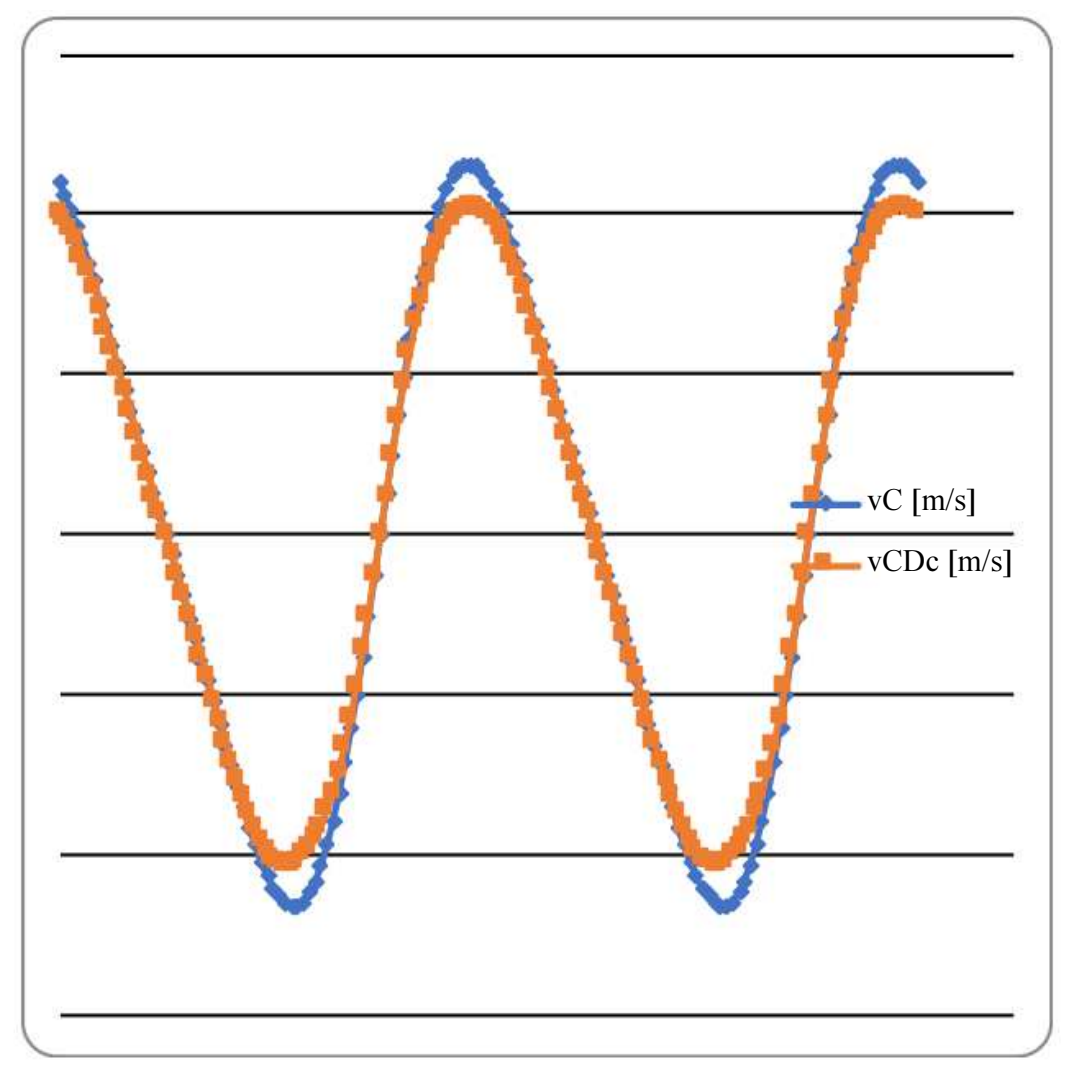

Fig. 2: The velocities of the piston, when the engine works in the compressor system 


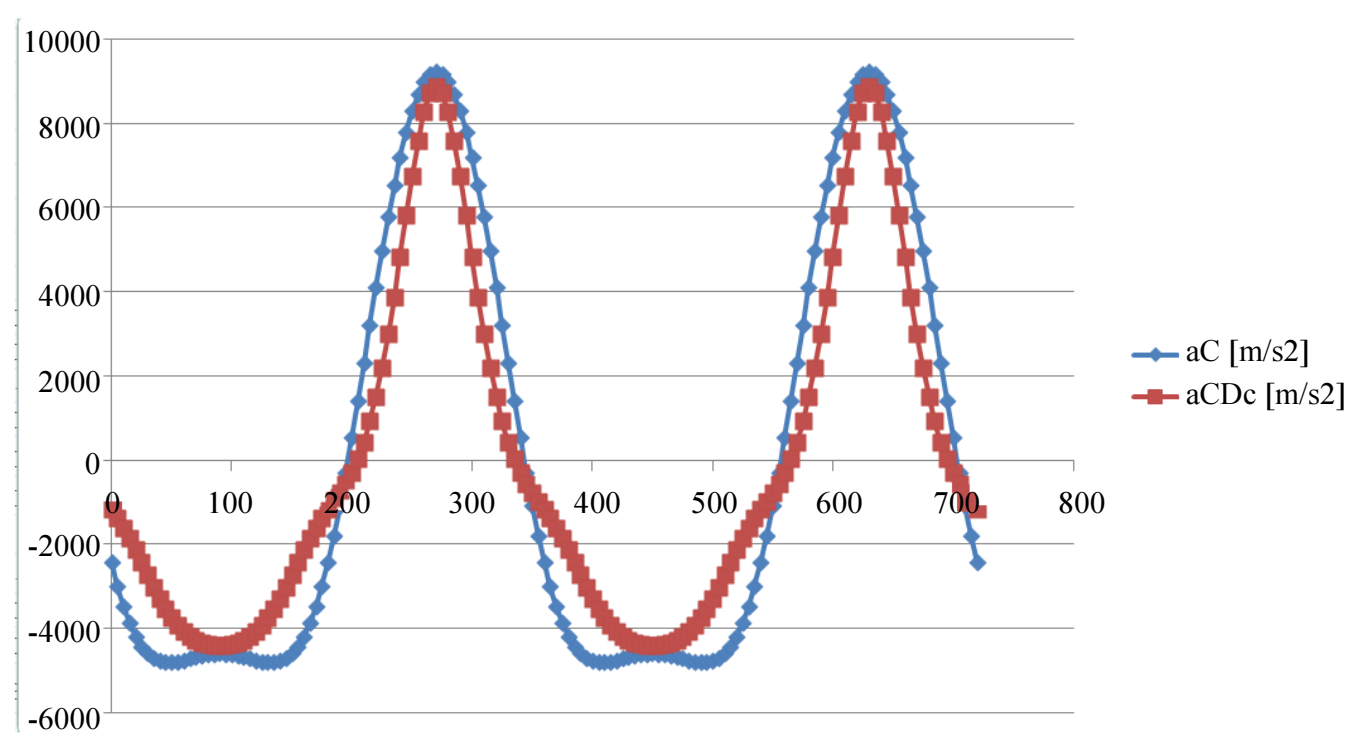

Fig. 3: The accelerations of the piston, when the engine works in the compressor system

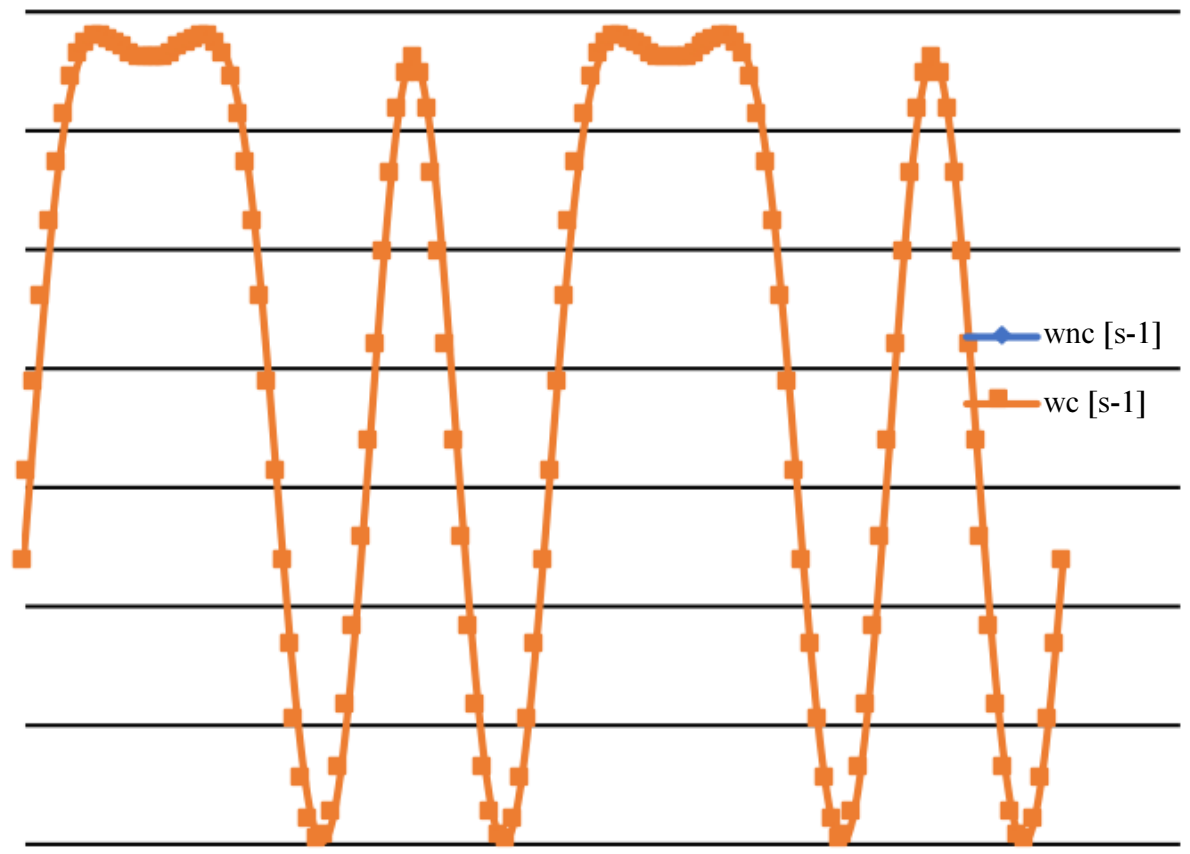

Fig. 4: The angular velocities of the motor shaft, when the engine works in the compressor system 


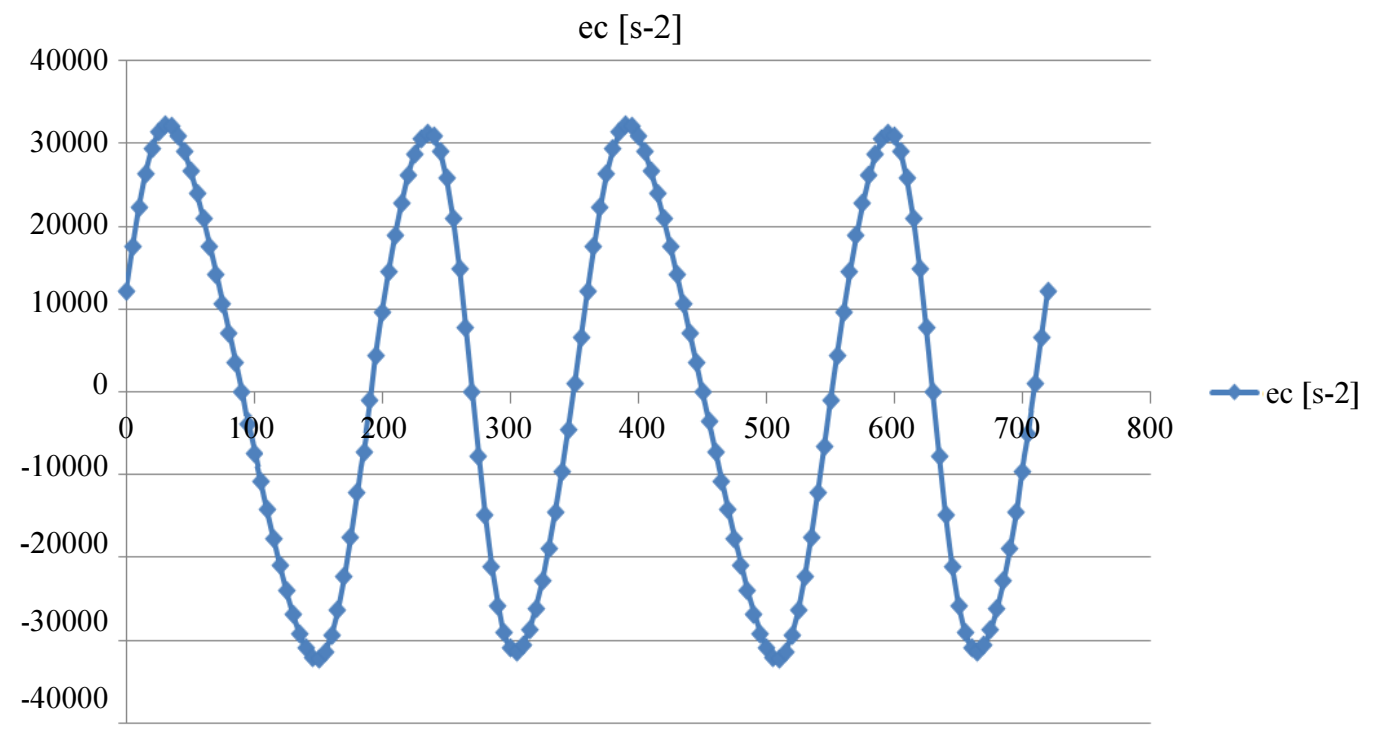

Fig. 5: The angular accelerations of the motor shaft, when the engine works in the compressor system

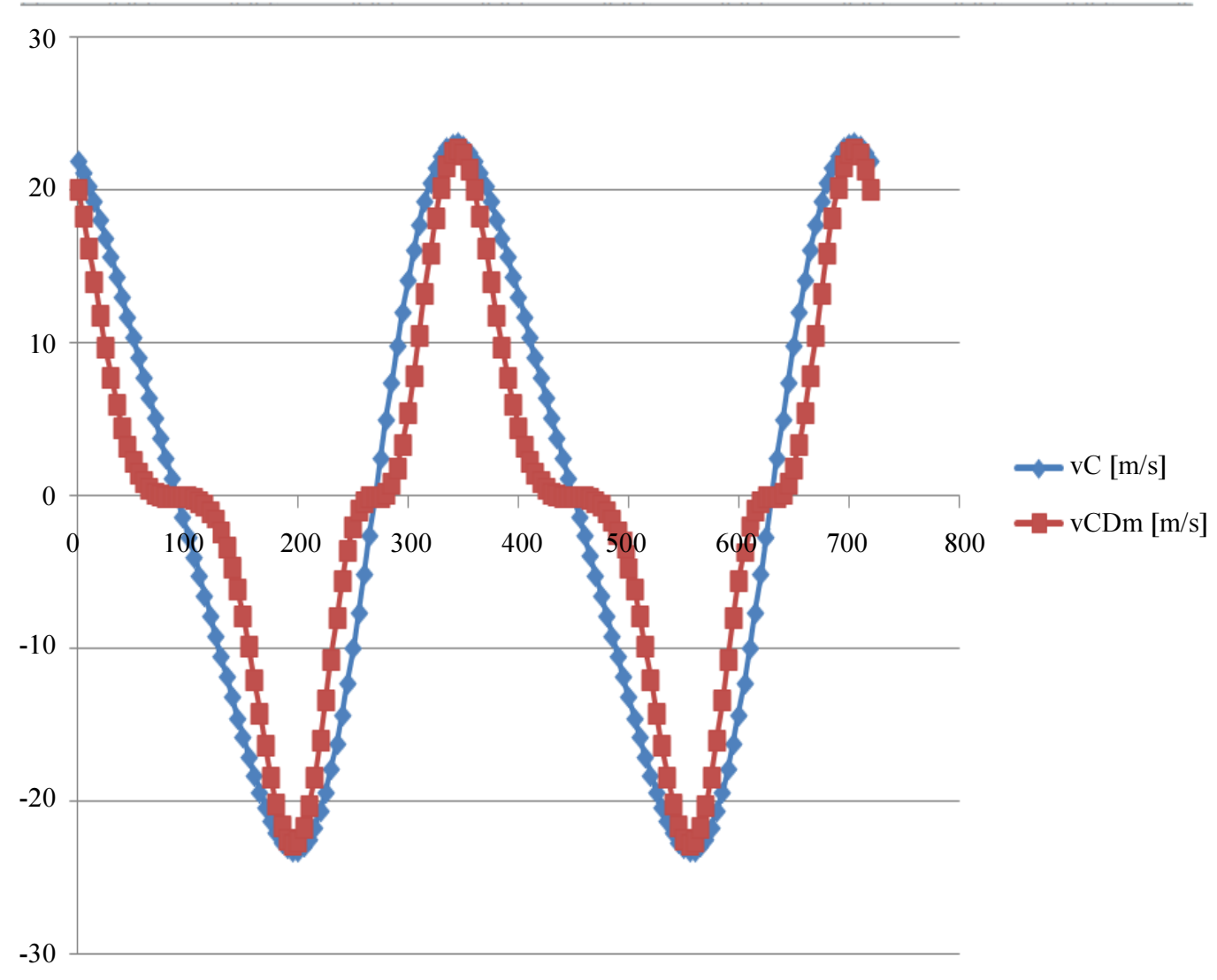

Fig. 6: The velocities of the piston, when the engine works in the motor system 


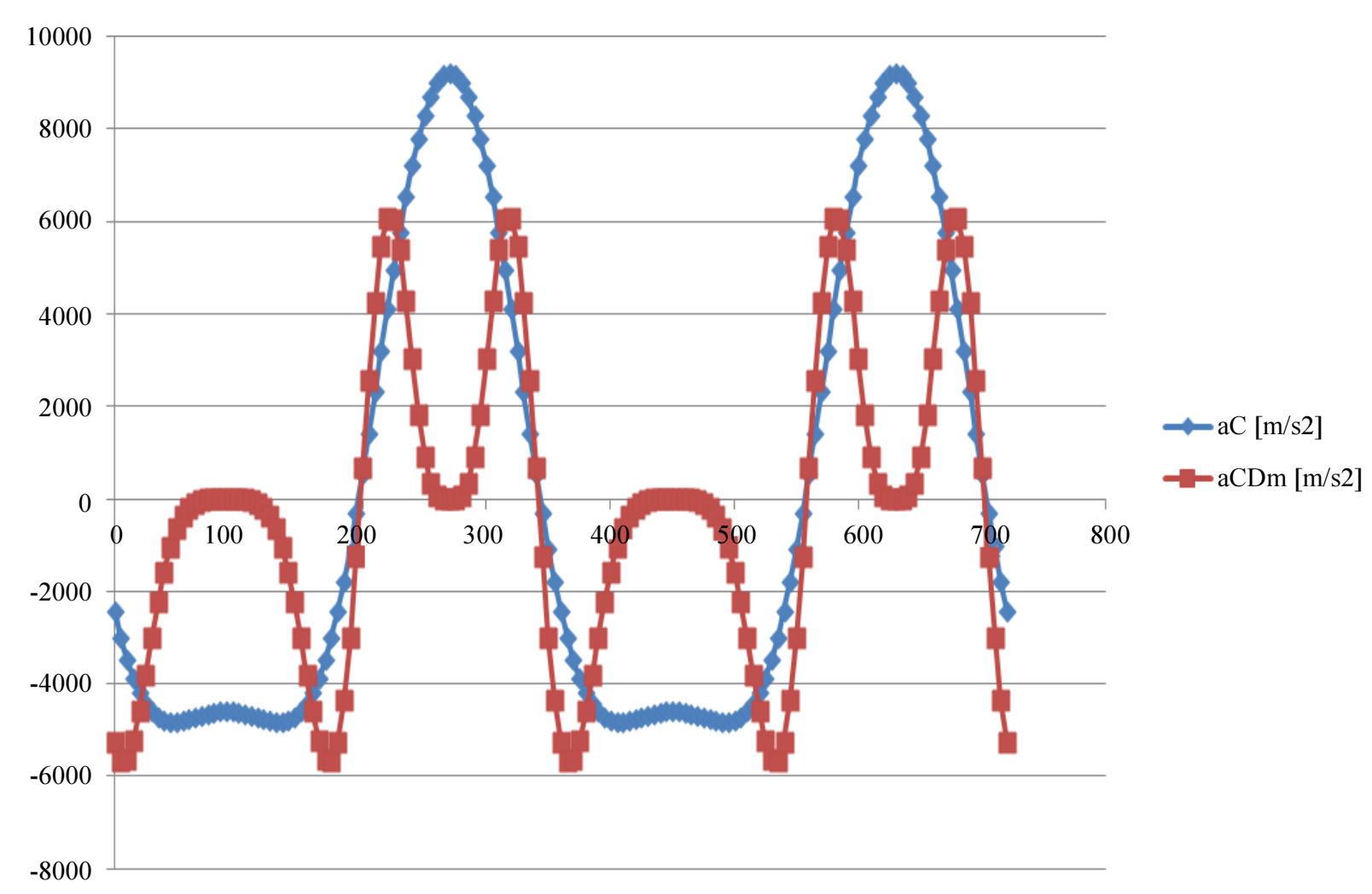

Fig. 7: The accelerations of the piston, when the engine works in the motor system

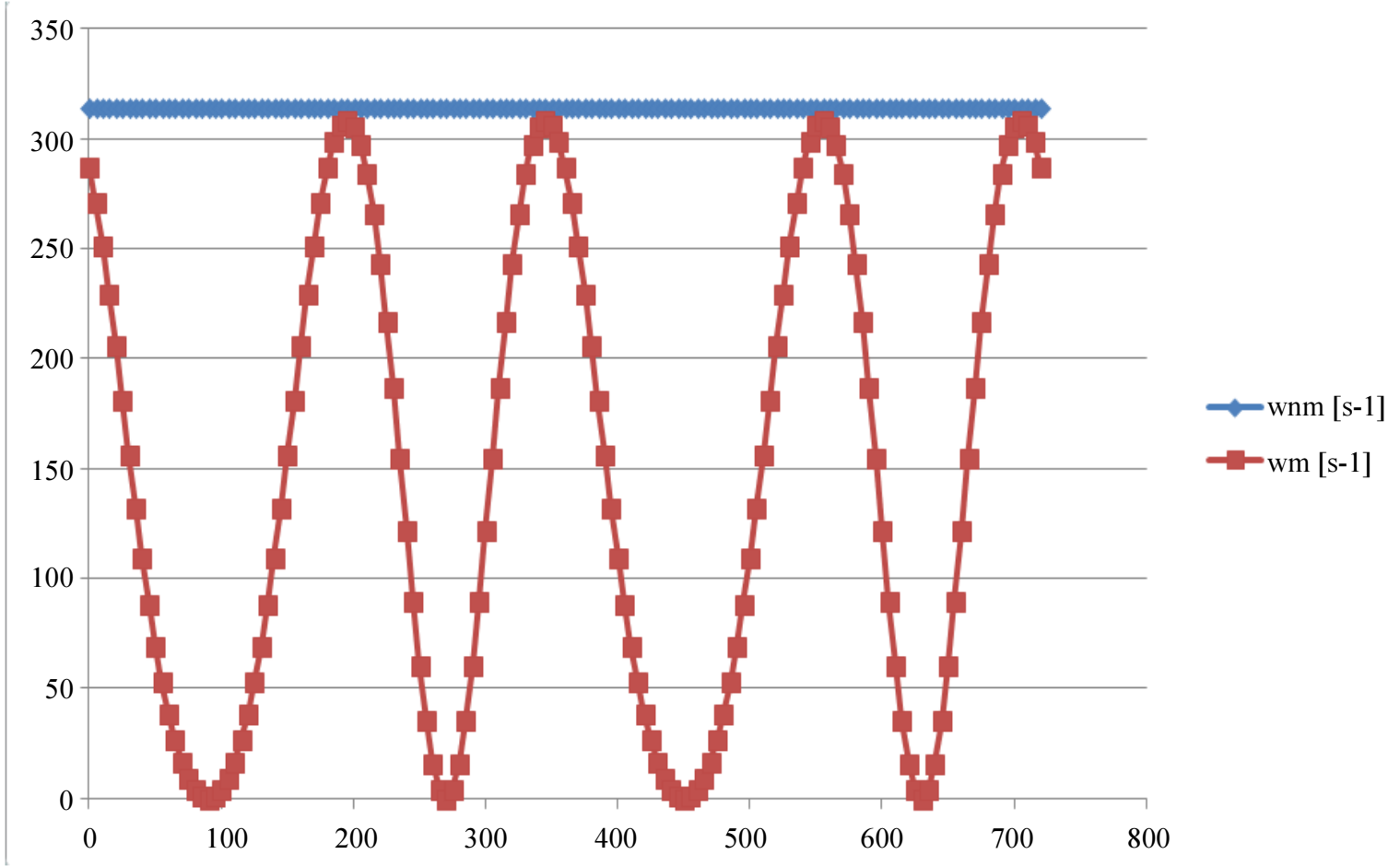

Fig. 8: The angular velocities of the motor shaft, when the engine works in the motor system 


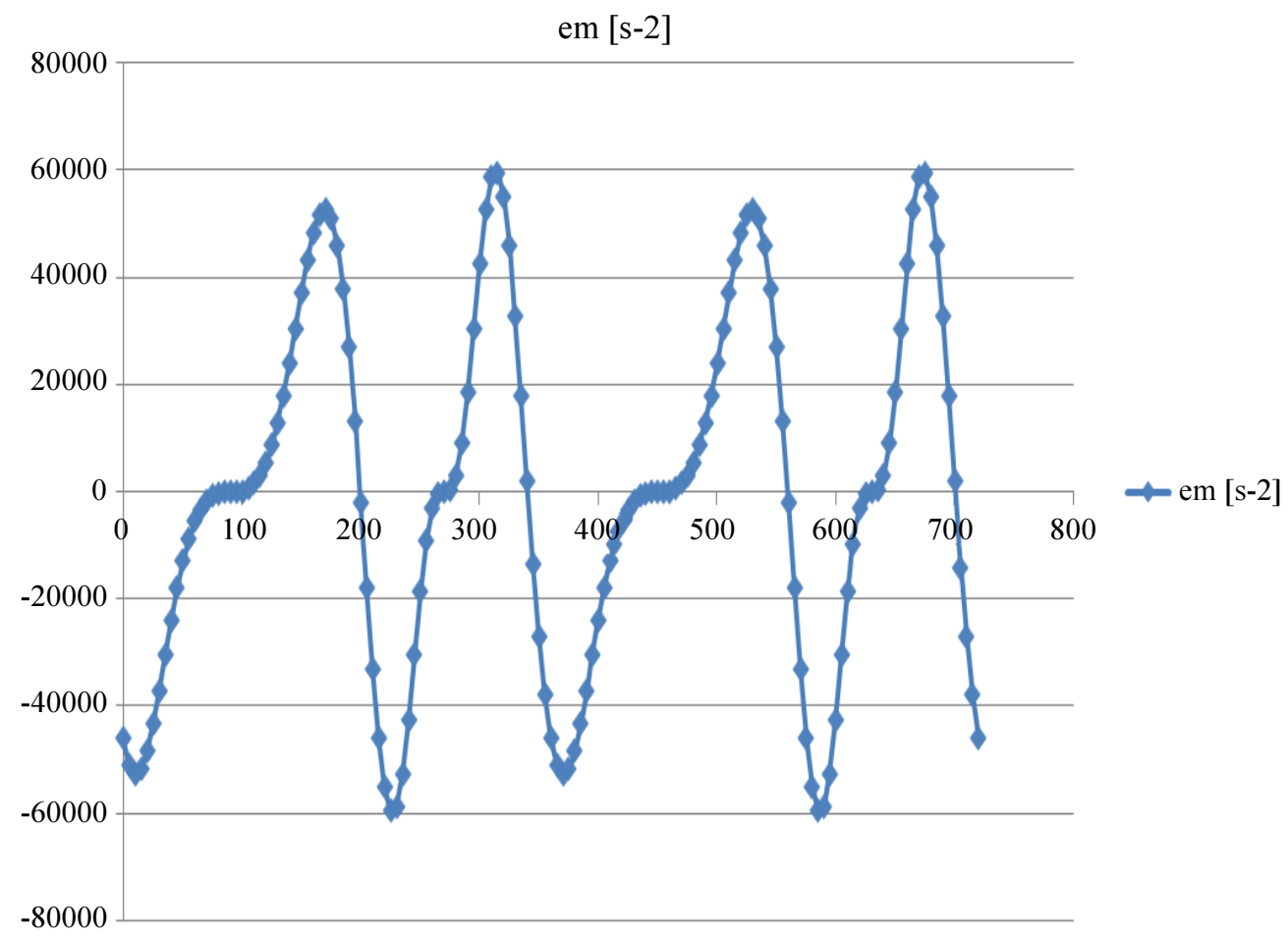

Fig. 9: The angular accelerations of the motor shaft, when the engine works in the motor system

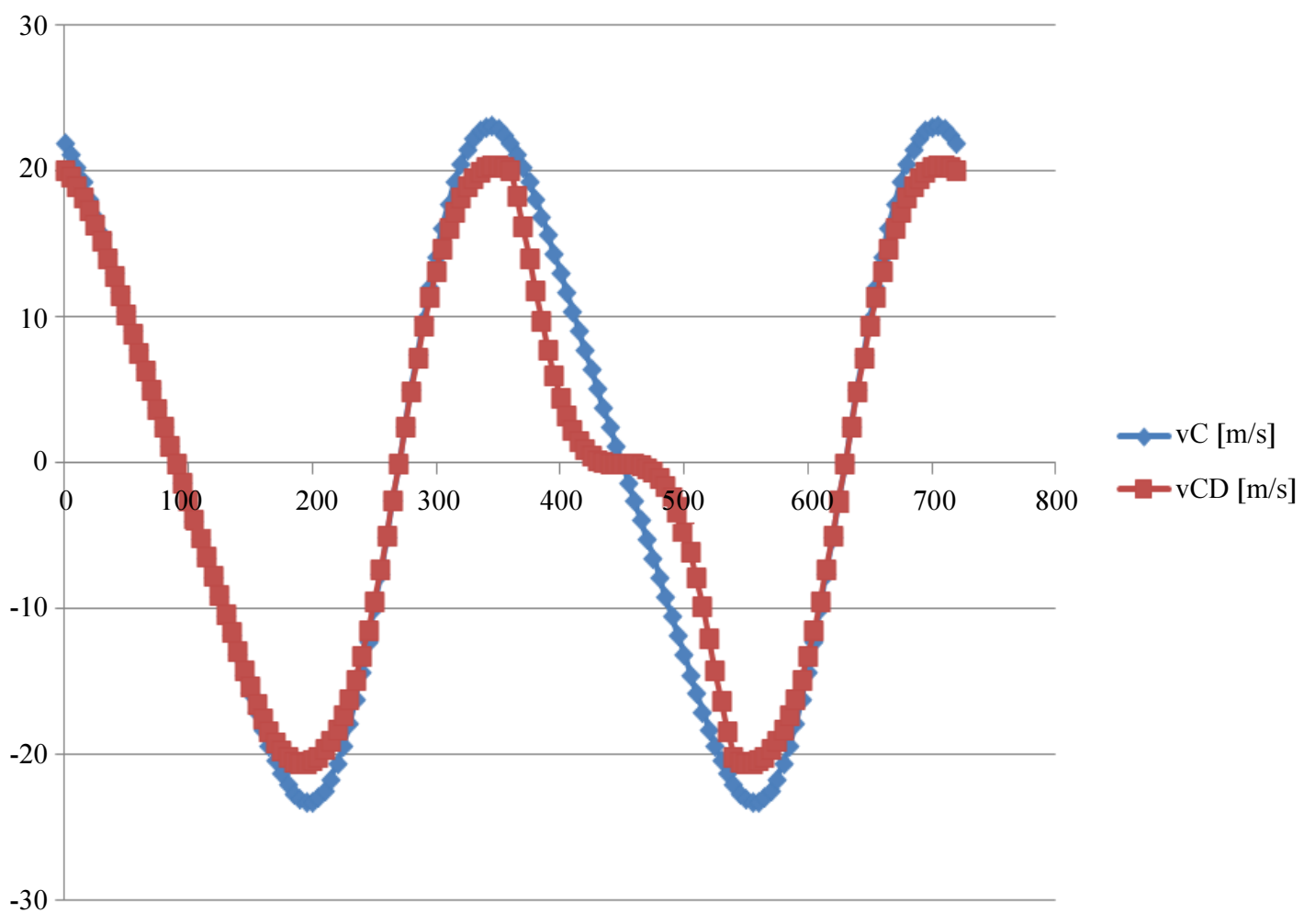

Fig. 10: The velocities of the piston, for a mono cylinder engine 


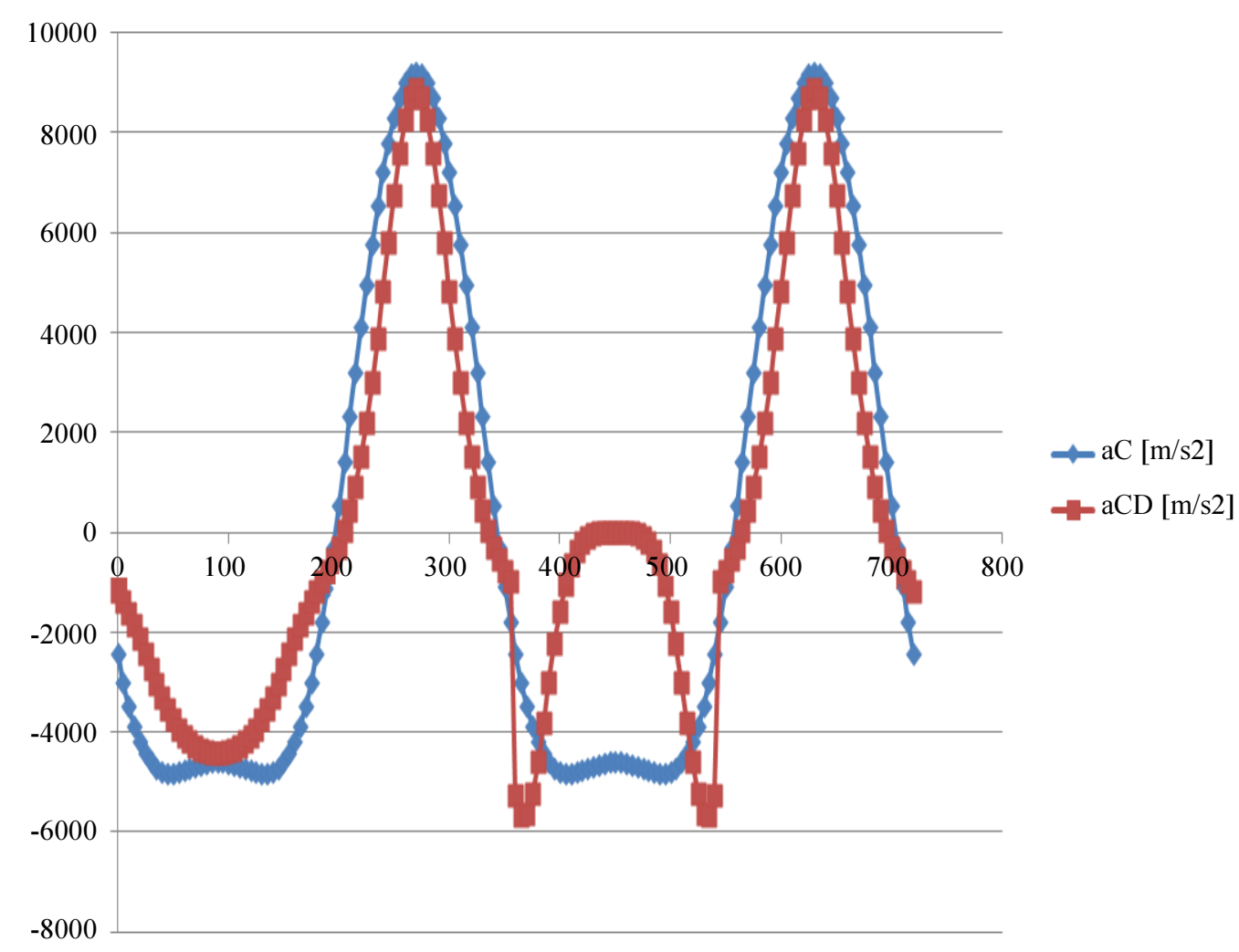

Fig. 11: The accelerations of the piston, for a mono cylinder engine, oriented upside down

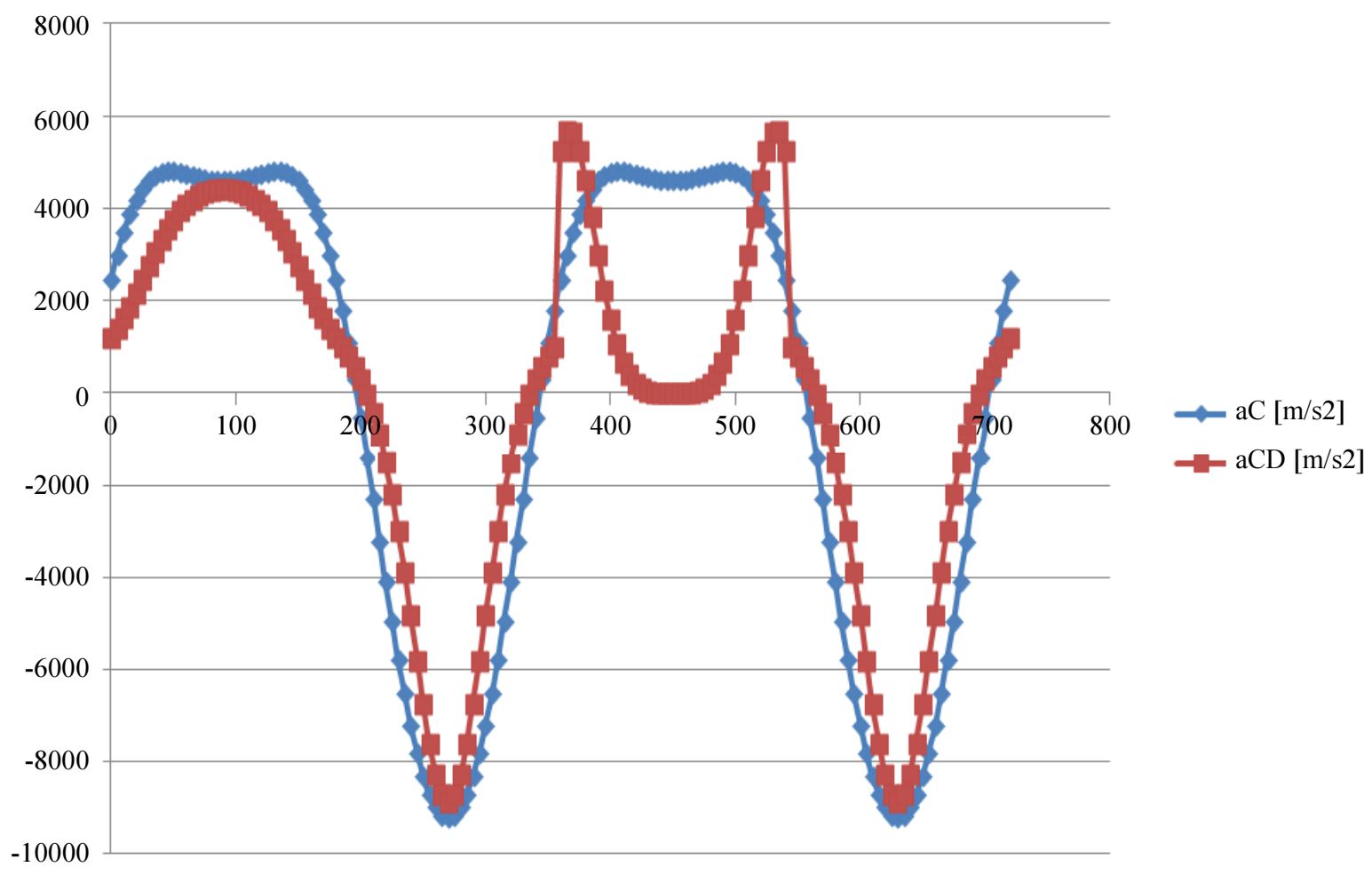

Fig. 12: The accelerations of the piston, for a mono cylinder engine, oriented head upward 


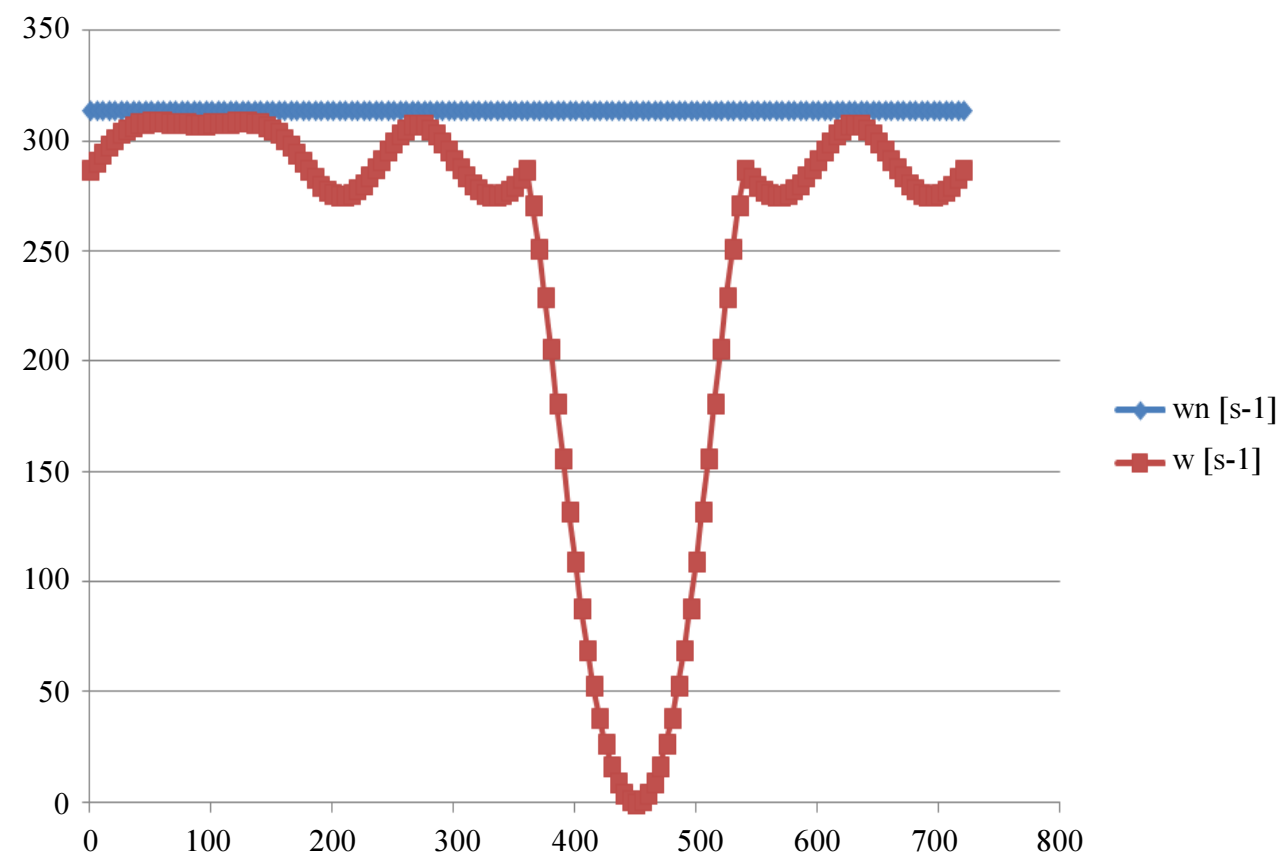

Fig. 13: The angular velocities of the motor shaft, for a mono cylinder engine

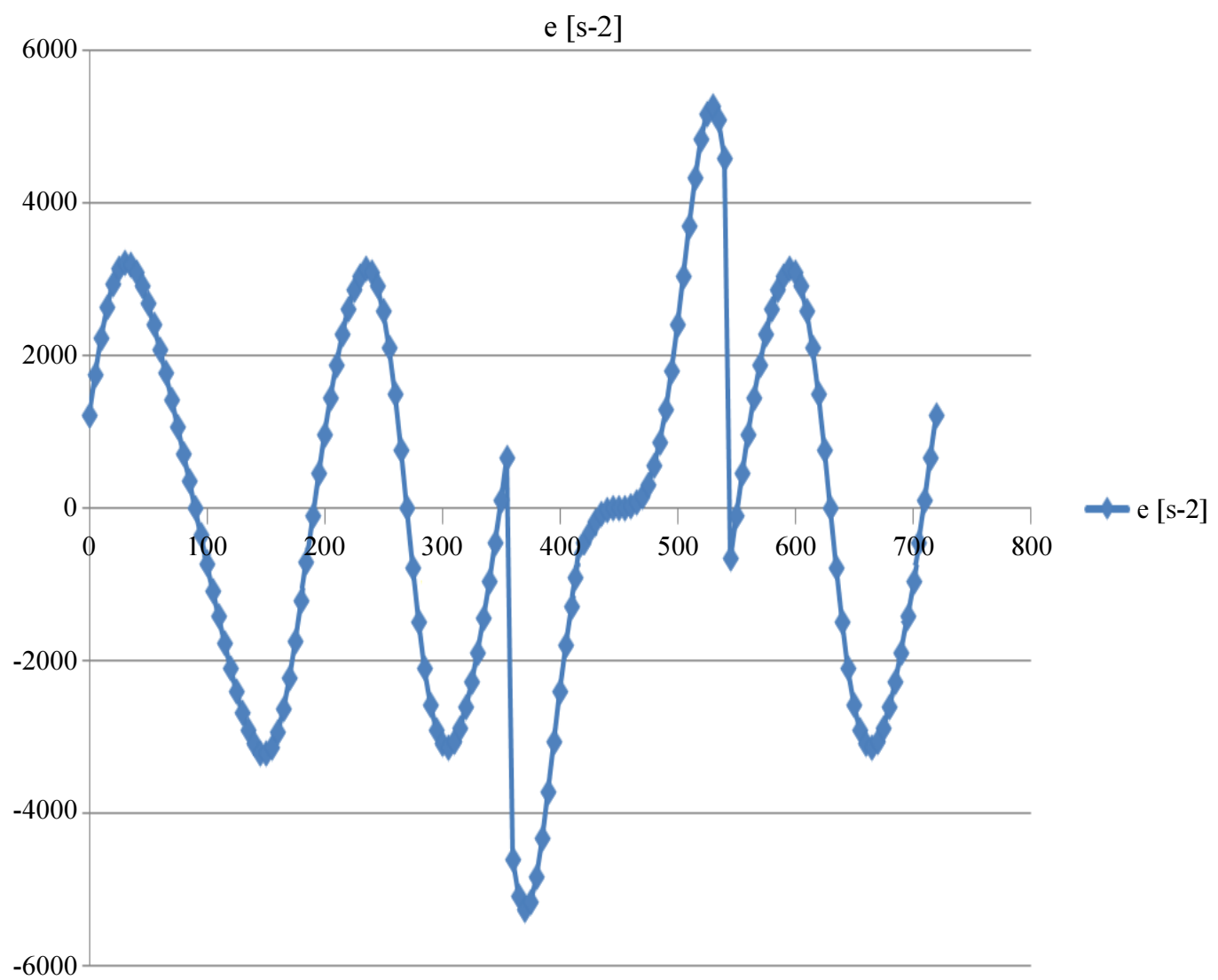

Fig. 14: The angular accelerations of the motor shaft, for a mono cylinder engine 


\section{Discussion}

Only dynamic coefficient of inertia and the influence of kinematic couplings in the system were used in the analyzed sample.

The dynamic coefficient due to elasticity and deformation in the system has not been taken into account since the overwhelming influence of the inertial forces is impacted by additional dynamic changes and also by the kinematic couplings in the system and the elastic deformations do not greatly influence the dynamics of the system in the case of the example remembered.

If a robot was being discussed, things were similar, as in the case of various vehicles and various mechanisms and machines. However, for rigid memory transmissions, elastic deformations are important, which is why they should be considered in such systems.

During the 1970s energy crisis, the production and sale of cars equipped with internal combustion engines increased from several million to over sixty million a year and the world fleet ranged from tens of millions to billions.

As long as we produce electricity and heat by burning fossil fuels, it is useless to try to replace all electric motors as electricity and the pollution will be even greater. However, it is good to continually improve thermal motors to reduce fuel consumption.

Otto and diesel engines are today the best solution for transporting our daily work together with electric and reaction engines. For these reasons, it is imperative that we can accurately calculate the efficiency of the engine so that it can be increased continuously. However, it is good to continually improve thermal motors to reduce fuel consumption.

Since today the moments of mass inertia, i.e., the masses of rotation motion elements considered around the axis of rotation, are less known, one reintroduce in this paper some main cases (Fig. 15-27), (Petrescu et al., 2016).

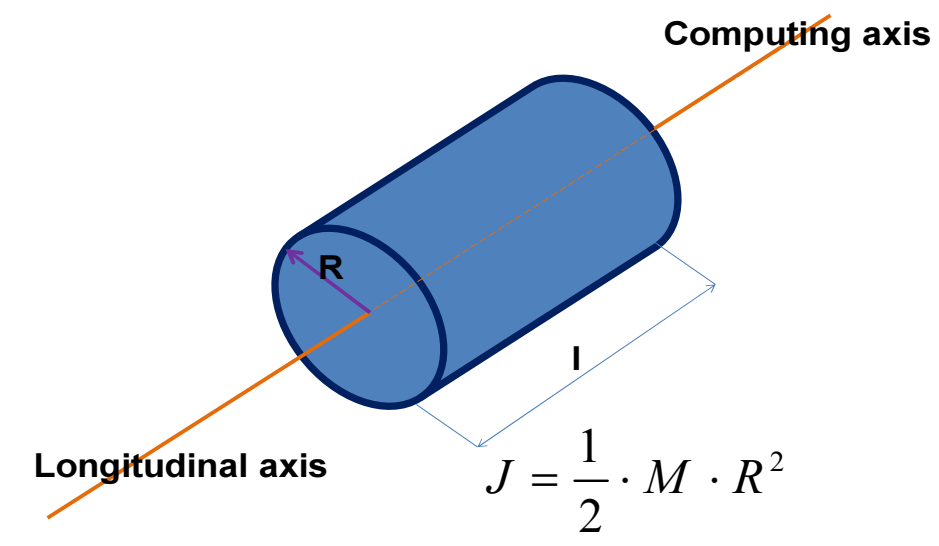

Fig. 15: Mass moment of inertia of a cylinder or a disc, fixed to the longitudinal axis of the cylinder or disc

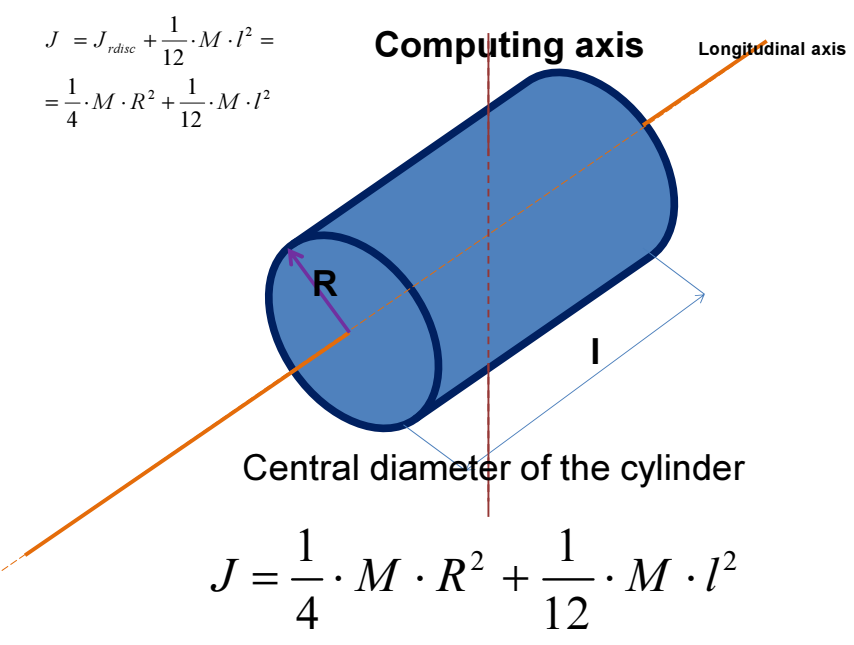

Fig. 16: Mass moment of inertia of a cylinder, determined in about an axis central diametral 


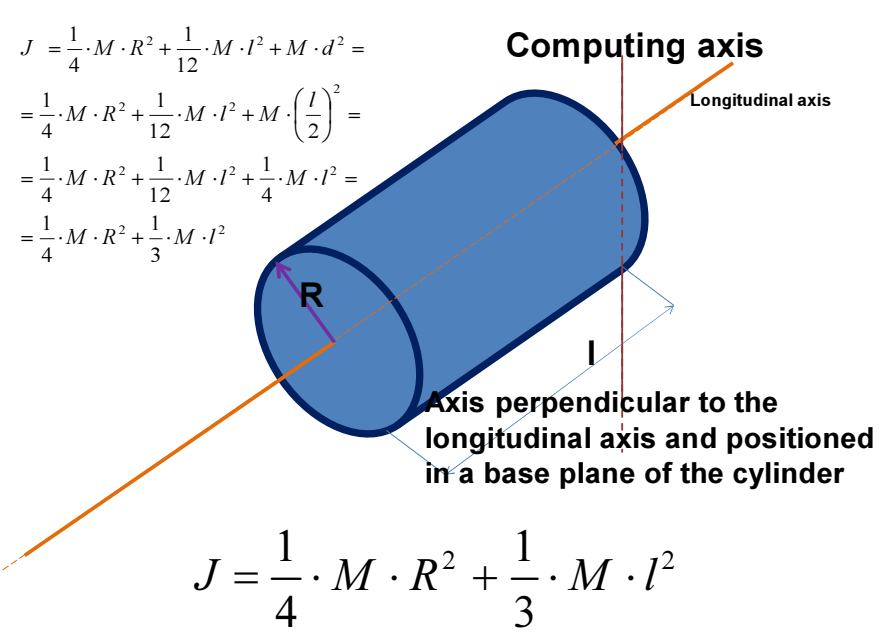

Fig. 17: Mass moment of inertia of the cylinder, caused about an axis lying in the plane of the end of the cylinder perpendicular to the longitudinal axis

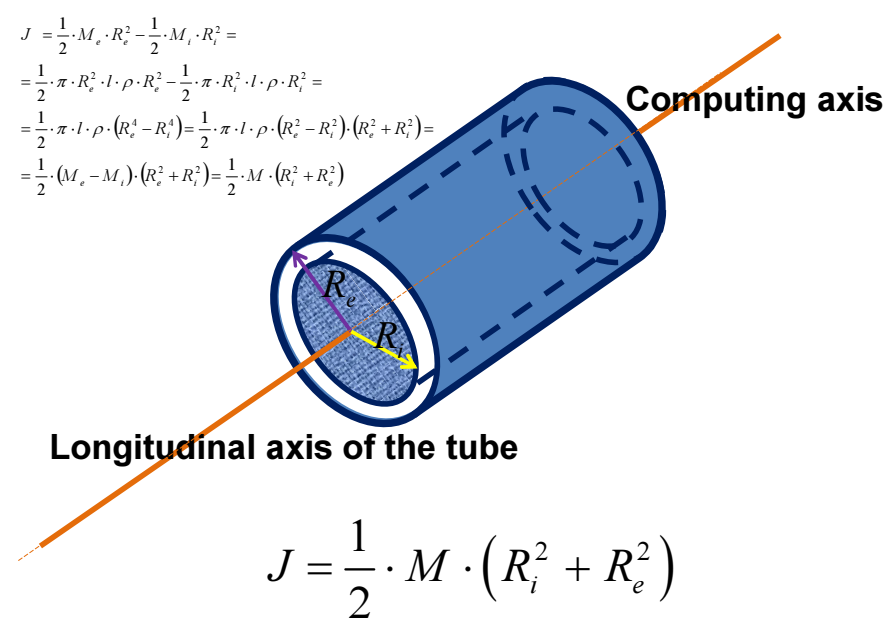

Fig. 18: Mass moment of inertia to a tube (pipe or annulus) determined about the longitudinal axis

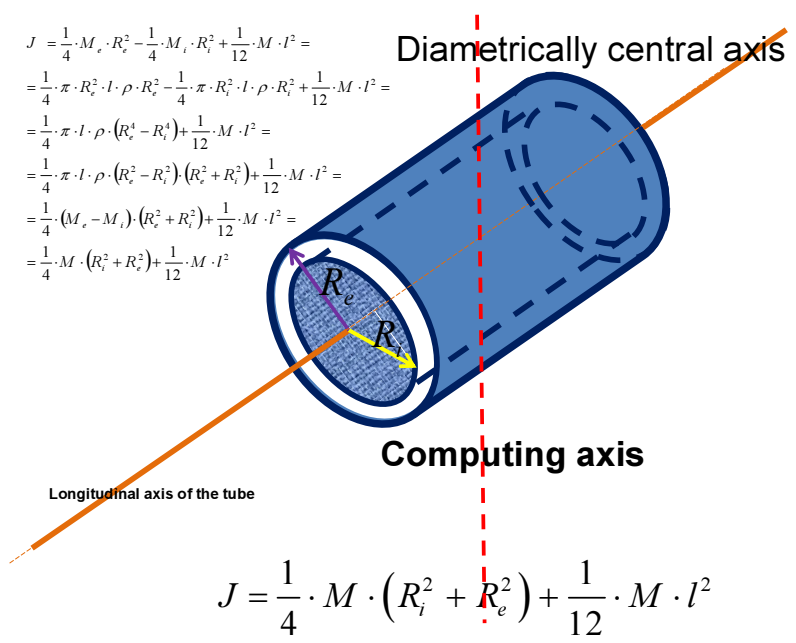

Fig. 19: Mass moment of inertia to a tube (pipe or annulus) determined about the diametrically central axis 


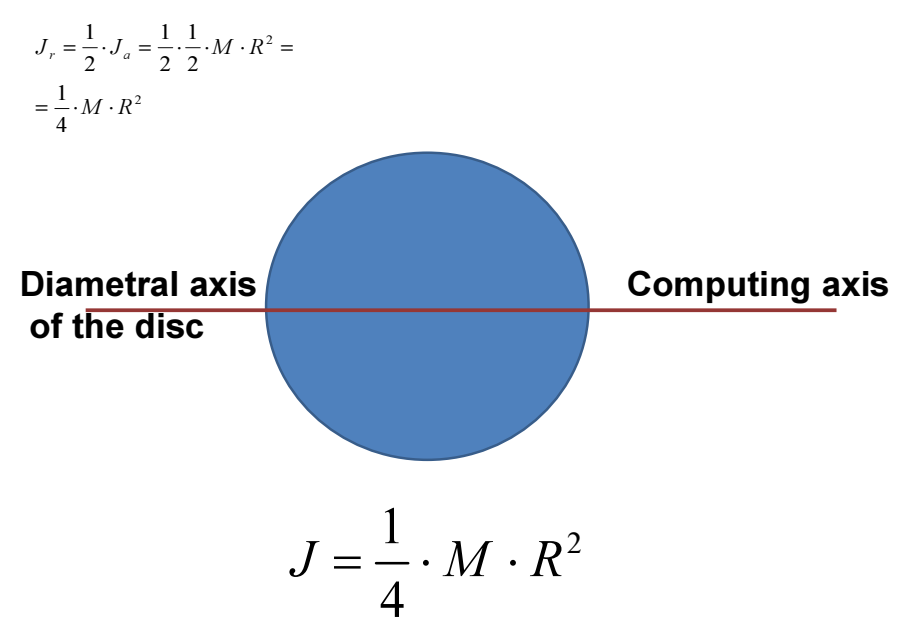

Fig. 20: Mass moment of inertia to a disc determined to the radial (diametral) axis of the disc

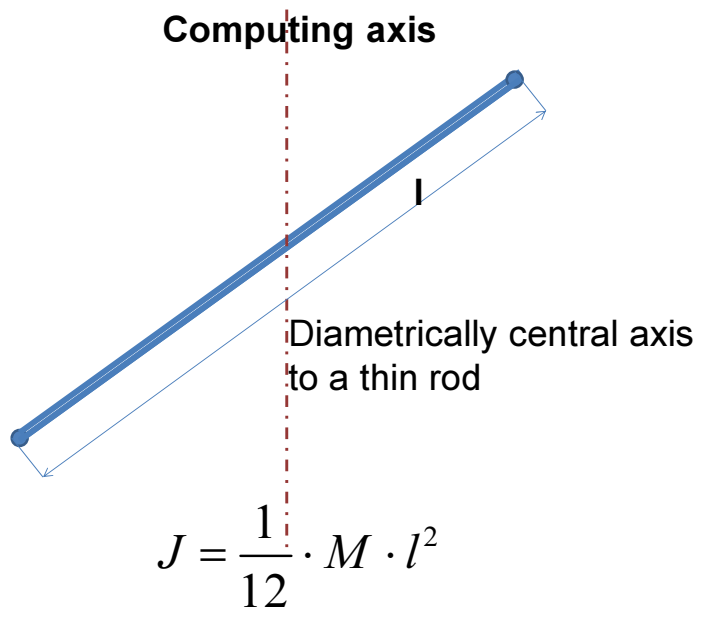

Fig. 21: Mass moment of inertia to a thin rod, led around an axis passing through a central diameter of the rod

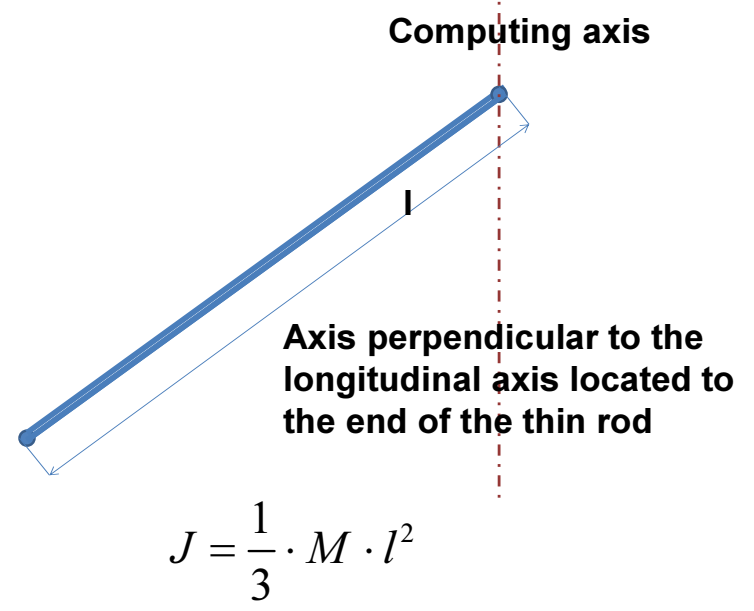

Fig. 22: Mass moment of inertia of a thin rod, determined about an axis located at one of the rod ends, perpendicular to the longitudinal axis of the stem 


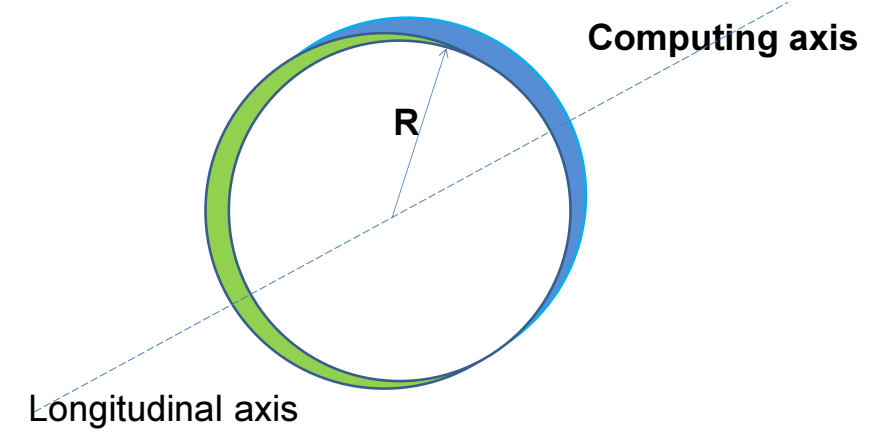

$$
J=M \cdot R^{2}
$$

Fig. 23: Mass moment of inertia of a ring fixed (calculated) around the longitudinal axis of the ring

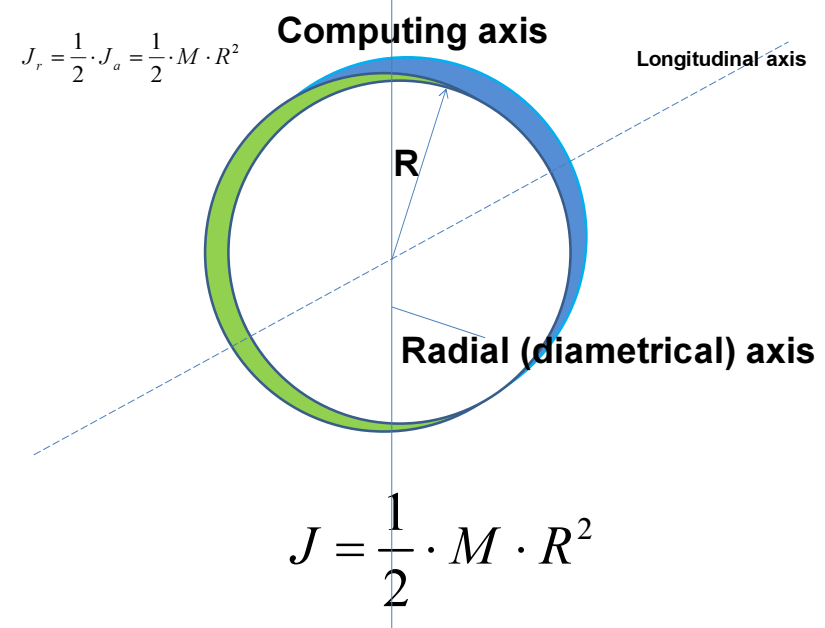

Fig. 24: Mass moment of inertia of a ring fixed around a radial (diametrical) axis of the ring

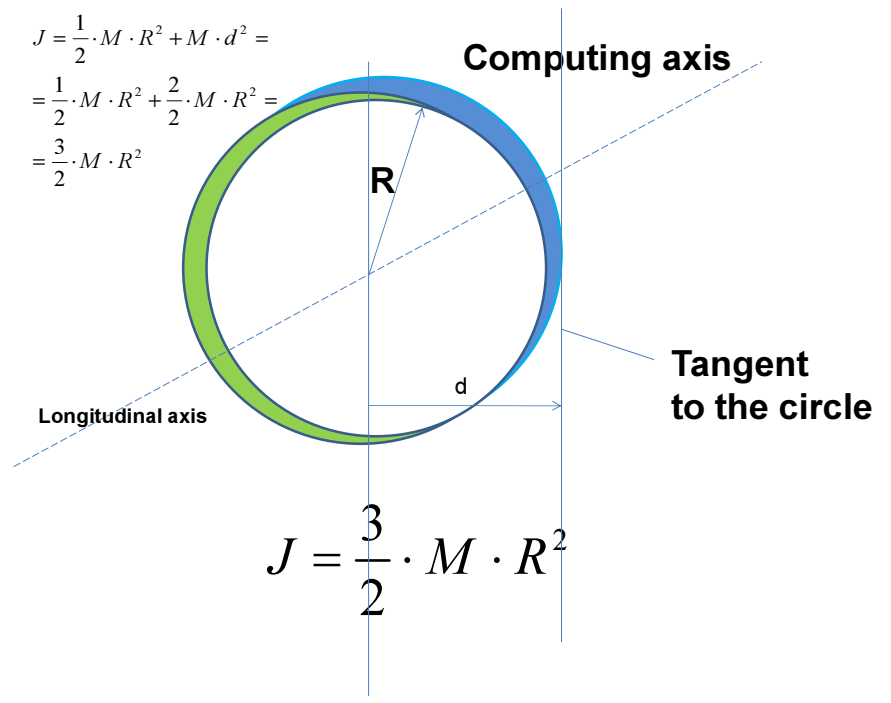

Fig. 25: Mass moment of inertia of a ring fixed around an axis tangent to the circle of the ring 


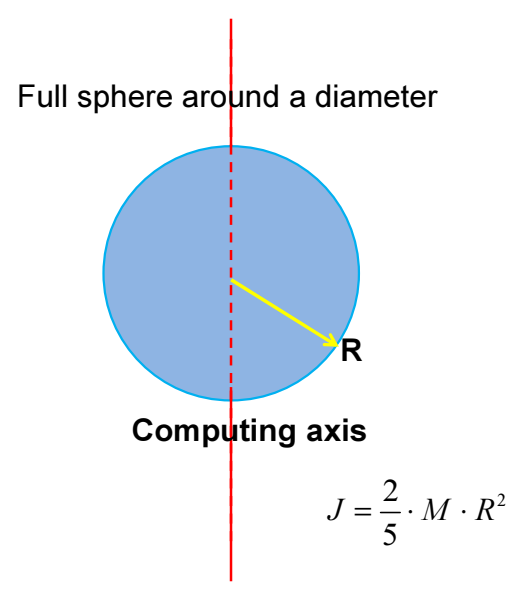

Fig. 26: Mass moment of inertia to a full sphere determined around a diameter

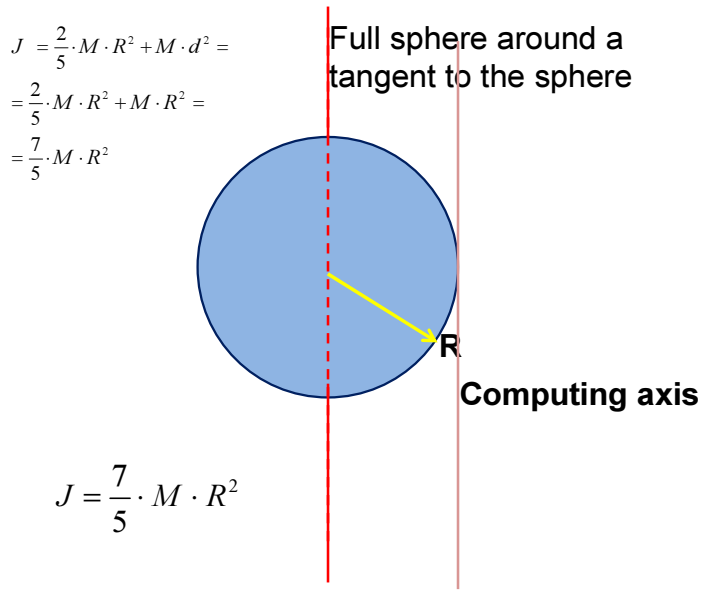

Fig. 27: Mass moment of inertia to a full sphere determined around a tangent to the sphere

New materials presented in this paper open a new perspective in the study of general mechanical dynamics (Rulkov et al., 2016; Agarwala, 2016; Babayemi, 2016; Gusti and Semin, 2016; Mohamed et al., 2016; Wessels and Raad, 2016; Maraveas et al., 2015; Khalil, 2015; Rhode-Barbarigos et al., 2015; Takeuchi et al., 2015; Li et al., 2015; Vernardos and Gantes, 2015; Bourahla and Blakeborough, 2015; Stavridou et al., 2015; Ong et al., 2015; Dixit and Pal, 2015; Rajput et al., 2016; Rea and Ottaviano, 2016; Zurfi and Zhang, $2016 \mathrm{a}-\mathrm{b}$; Zheng and Li, 2016; Buonomano et al., 2016a; 2016b; Faizal et al., 2016; Ascione et al., 2016; Elmeddahi et al., 2016; Calise et al., 2016; Morse et al., 2016; Abouobaida, 2016; Rohit and Dixit, 2016; Kazakov et al., 2016; Alwetaishi, 2016; Riccio et al., 2016a; 2016b; Iqbal, 2016; Hasan and El-Naas, 2016; Al-Hasan and AlGhamdi, 2016; Jiang et al., 2016; Sepúlveda, 2016; Martins et al., 2016; Pisello et al., 2016; Jarahi, 2016; Mondal et al., 2016; Mansour, 2016; Al Qadi et al., 2016b; Campo et al., 2016; Samantaray et al., 2016; Malomar et al., 2016; Rich and Badar, 2016; Hirun, 2016; Bucinell, 2016; Nabilou, 2016b; Barone et al., 2016; Chisari and Bedon, 2016; Bedon and Louter, 2016; Santos and Bedon, 2016; Minghini et al., 2016; Bedon, 2016; Jafari et al., 2016; Chiozzi et al., 2016; Orlando and Benvenuti, 2016; Wang and Yagi, 2016; Obaiys et al., 2016; Ahmed et al., 2016; Jauhari et al., 2016; Syahrullah and Sinaga, 2016; Shanmugam, 2016; Jaber and Bicker, 2016; Wang et al., 2016; Moubarek and Gharsallah, 2016; Amani, 2016; Shruti, 2016; Pérezde León et al., 2016; Mohseni and Tsavdaridis, 2016; Abu-Lebdeh et al., 2016; Serebrennikov et al., 2016; Budak et al., 2016; Augustine et al., 2016; Jarahi and Seifilaleh, 2016; Nabilou, 2016a; You et al., 2016; AL Qadi et al., 2016a; Rama et al., 2016; Sallami et al., 2016; Huang et al., 2016; Ali et al., 2016; Kamble and Kumar, 2016; Saikia and Karak, 2016; Zeferino et al., 2016; Pravettoni et al., 2016; Bedon and Amadio, 2016; 
Chen and Xu, 2016; Mavukkandy et al., 2016; Yeargin et al., 2016; Madani and Dababneh, 2016; Alhasanat et al., 2016; Elliott et al., 2016; Suarez et al., 2016; Kuli et al., 2016; Waters et al., 2016; Montgomery et al., 2016; Lamarre et al., 2016; Daud et al., 2008; Taher et al., 2008; Zulkifli et al., 2008; Pourmahmoud, 2008; Pannirselvam et al., 2008; $\mathrm{Ng}$ et al., 2008; El-Tous, 2008; Akhesmeh et al., 2008; Nachiengtai et al., 2008; Moezi et al., 2008; Boucetta, 2008; Darabi et al., 2008; Semin and Bakar, 2008; AlAbbas, 2009; Abdullah et al., 2009; Abu-Ein, 2009; Opafunso et al., 2009; Semin et al., 2009a; 2009b; 2009c; Zulkifli et al., 2009; Marzuki et al., 2015; Bier and Mostafavi, 2015; Momta et al., 2015; Farokhi and Gordini, 2015; Khalifa et al., 2015; Yang and Lin, 2015; Chang et al., 2015; Demetriou et al., 2015; Rajupillai et al., 2015; Sylvester et al., 2015; Ab-Rahman et al., 2009; Abdullah and Halim, 2009; Zotos and Costopoulos, 2009; Feraga et al., 2009; Bakar et al., 2009; Cardu et al., 2009; Bolonkin, 2009a; 2009b; Nandhakumar et al., 2009; Odeh et al., 2009; Lubis et al., 2009; Fathallah and Bakar, 2009; Marghany and Hashim, 2009; Kwon et al., 2010; Aly and Abuelnasr, 2010; Farahani et al., 2010; Ahmed et al., 2010; Kunanoppadon, 2010; Helmy and ElTaweel, 2010; Qutbodin, 2010; Pattanasethanon, 2010; Fen et al., 2011; Thongwan et al., 2011; Theansuwan and Triratanasirichai, 2011; Al Smadi, 2011; Tourab et al., 2011; Raptis et al., 2011; Momani et al., 2011; Ismail et al., 2011; Anizan et al., 2011; Tsolakis and Raptis, 2011; Abdullah et al., 2011; Kechiche et al., 2011; Ho et al., 2011; Rajbhandari et al., 2011; Aleksic and Lovric, 2011; Kaewnai and Wongwises, 2011; Idarwazeh, 2011; Ebrahim et al., 2012; Abdelkrim et al., 2012; Mohan et al., 2012; Abam et al., 2012; Hassan et al., 2012; Jalil and Sampe, 2013; Jaoude and El-Tawil, 2013; Ali and Shumaker, 2013; Zhao, 2013; El-Labban et al., 2013; Djalel et al., 2013; Nahas and Kozaitis, 2013; Petrescu and Petrescu, 2014a; 2014b; 2014c; 2014d; 2014e; 2014f; 2014g; 2014h; 2014i; 2015a; 2015b; 2015c; 2015d; 2015e; 2016a; 2016b; 2016c; 2016d; Fu et al., 2015; Al-Nasra et al., 2015; Amer et al., 2015; Sylvester et al., 2015b; Kumar et al., 2015; Gupta et al., 2015; Stavridou et al., 2015b; Casadei, 2015; Ge and $\mathrm{Xu}, 2015$; Moretti, 2015; Wang et al., 2015).

\section{Dynamic Kinematics to the Rod-Crank-Piston System}

The cinematics of the piston crankshaft mechanism of Fig. 28 is generally known to be solved by the relationships (II.1-13):

$$
\left\{\begin{array}{l}
r \cdot \cos \varphi+l \cdot \cos \psi=-e \\
r \cdot \sin \varphi+l \cdot \sin \psi=y_{B}
\end{array}\right.
$$

$$
\begin{aligned}
& \cos \psi=-\frac{e+r \cdot \cos \varphi}{l} \\
& s=y_{B}=r \cdot \sin \varphi+l \cdot \sin \psi \\
& \left\{\begin{array}{l}
-r \cdot \dot{\varphi} \cdot \sin \varphi-l \cdot \dot{\psi} \cdot \sin \psi=0 \\
r \cdot \dot{\varphi} \cdot \cos \varphi+l \cdot \dot{\psi} \cdot \cos \psi=\dot{y}_{B}
\end{array}\right. \\
& \dot{\psi}=-\frac{r \cdot \sin \varphi}{l \cdot \sin \psi} \cdot \dot{\varphi} \\
& \dot{y}_{B}=r \cdot \dot{\varphi} \cdot \cos \varphi+l \cdot \dot{\psi} \cdot \cos \psi \\
& \left\{\begin{array}{l}
-r \cdot \dot{\varphi}^{2} \cdot \cos \varphi-l \cdot \dot{\psi}^{2} \cdot \cos \psi-l \cdot \ddot{\psi} \cdot \sin \psi=0 \\
-r \cdot \dot{\varphi}^{2} \cdot \sin \varphi-l \cdot \dot{\psi}^{2} \cdot \sin \psi+l \cdot \ddot{\psi} \cdot \cos \psi=\ddot{y}_{B}
\end{array}\right. \\
& \ddot{\psi}=-\frac{r \cdot \dot{\varphi}^{2} \cdot \cos \varphi+l \cdot \dot{\psi}^{2} \cdot \cos \psi}{l \cdot \sin \psi} \\
& \ddot{y}_{B}=l \cdot \ddot{\psi} \cdot \cos \psi-r \cdot \dot{\varphi}^{2} \cdot \sin \varphi-l \cdot \dot{\psi}^{2} \cdot \sin \psi \\
& \alpha=\psi-90 \\
& \left\{\begin{array}{l}
\cos \alpha=\sin \psi \\
\sin \alpha=-\cos \psi
\end{array}\right. \\
& \sin \alpha=\frac{e+r \cdot \cos \varphi}{l} \\
& \left\{\begin{array}{l}
v_{B}=\dot{y}_{B}=r \cdot \dot{\varphi} \cdot \cos \varphi+l \cdot \dot{\psi} \cdot \cos \psi \\
=r \cdot \dot{\varphi} \cdot \cos \varphi-\frac{r \cdot \dot{\varphi} \cdot \sin \varphi \cdot \cos \psi}{\sin \psi} \\
=\frac{r \cdot \dot{\varphi}}{\sin \psi} \cdot(\cos \phi \cdot \sin \psi-\sin \varphi \cdot \cos \psi) \\
=r \cdot \dot{\varphi} \cdot \frac{\sin (\psi-\varphi)}{\sin \psi}=r \cdot \omega \cdot \frac{\sin (\psi-\varphi)}{\sin \psi} \\
v_{B}=r \cdot \omega \cdot \frac{\sin (\psi-\varphi)}{\sin \psi}
\end{array}\right.
\end{aligned}
$$

In dynamic kinematics, the (dynamic) velocities are aligned in the direction of the forces as is natural, so that they no longer coincide with the known classical cinematic velocities (Fig. 29). Dynamic speeds due to forces occur, speeds that represent the dynamic kinematics (not to mention the influence of inertial forces, the influence that determines the final dynamic aspect of speeds). 


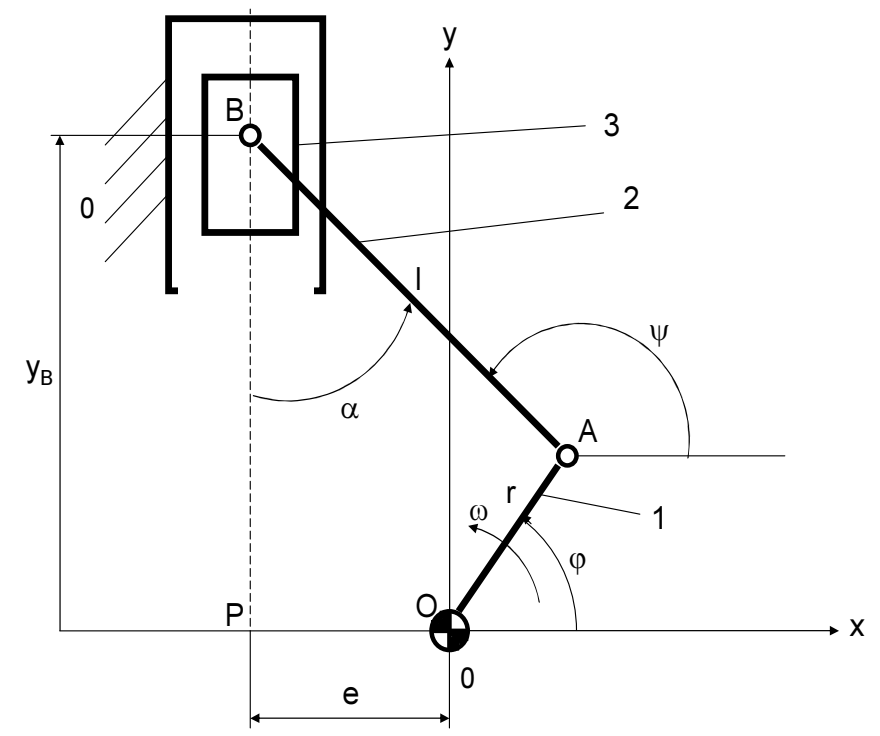

Fig. 28: The kinematic scheme of the piston crankshaft mechanism

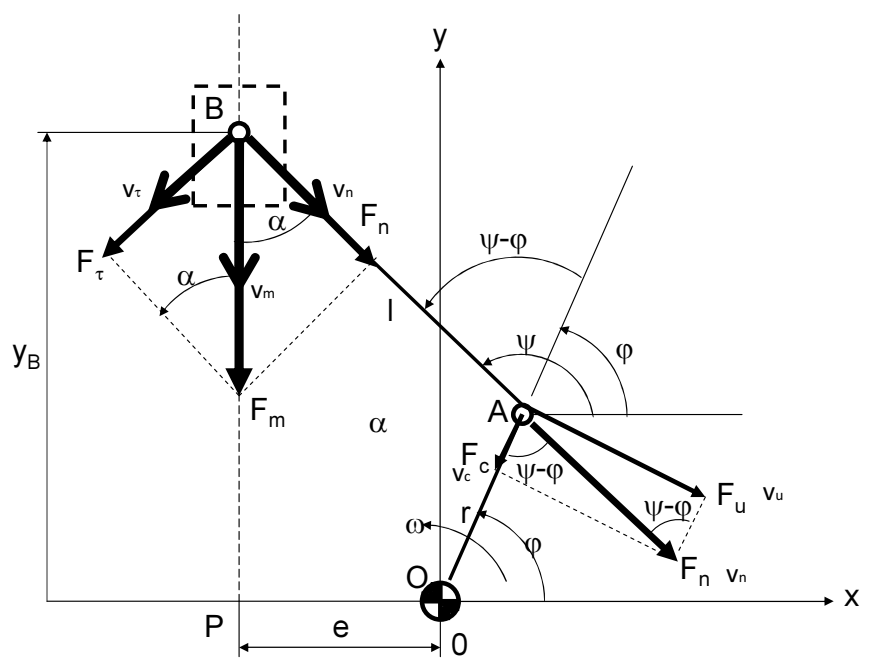

Fig. 29: Dynamic forces and speeds in the piston crank shaft mechanism, when power is transmitted from the piston to the crank

The dynamic kinematics (Petrescu, 2011) is, therefore, the kinematic study of the movements, speeds and accelerations resulting from the direction of operation of the speeds after the direction of the forces. The expressions of velocity in the dynamic kinematics are easily obtained, it is derived in relation to the time to determine the expressions of the accelerations in the dynamic kinematics and the expressions of the velocities are integrated in order to obtain the corresponding movements. Determining the movements in the dynamic cinematic becomes, therefore, more difficult.

To begin with, one will determine the speeds in the dynamic kinematics for piston cranked piston rod mechanism (Fig. 29).

One can write the relationships (II.14-16):

$$
\begin{aligned}
& v_{B}=v_{m} \\
& v_{n}=v_{m} \cdot \cos \alpha=v_{m} \cdot \sin \psi \\
& v_{u}=v_{n} \cdot \sin (\psi-\varphi)=v_{m} \cdot \sin \psi \cdot \sin (\psi-\varphi)
\end{aligned}
$$

One also want to find out the dynamic yield, more precisely the mechanical efficiency instantly when the mechanism has dynamic regimes and the speeds are those in the dynamic cinematic, the actuation of the mechanism being of the motor type, ie from the piston.

The useful force is determined by the relationship (II.17) presented in the previous chapter:

$$
F_{u}=F_{n} \cdot \sin (\psi-\varphi)=F_{m} \cdot \sin \psi \cdot \sin (\psi-\varphi)
$$


Puterea utilă se scrie în această situație sub forma II.18:

$\left\{\begin{array}{l}P_{u}=F_{u} \cdot v_{u} \\ F_{m} \cdot \sin \psi \cdot \sin (\psi-\varphi) \cdot v_{m} \cdot \sin \psi \cdot \sin (\psi-\varphi) \\ =F_{m} \cdot v_{m} \cdot \sin ^{2} \psi \cdot \sin ^{2}(\psi-\varphi)\end{array}\right.$

Expression of power consumed is given by relationship II.19:

$$
P_{c}=F_{m} \cdot v_{m}
$$

It can now determine the dynamic yield, more precisely instant dynamic yield (relationship II.20);

$\eta_{i}^{D M}=\frac{P_{u}}{P_{c}}=\sin ^{2} \psi \cdot \sin ^{2}(\psi-\varphi)=\eta_{i} \cdot D^{M}$

where, $\eta_{i}$ is the instantaneous mechanical efficiency of the crankshaft piston actuated by the piston and $D^{M}$ is a dynamic coefficient, which for the piston-driven piston rod (in Motor mode) is II.21:

$$
D^{M}=\sin ^{2}(\psi-\varphi)=\sin ^{2}(\varphi-\psi)
$$

In this case, let us recall that the instantaneous mechanical efficiency has the expression II.22:

$\eta_{i}=\sin ^{2} \psi$

It should be noted that the dynamic yield is precisely the product of the known, simple (cinematic) yield and the dynamic coefficient (relation II.23):

$$
\eta_{i}^{D M}=\eta_{i} \cdot D^{M}
$$

The kinematic expression of the speed of point $B$ (relationship II.24) is known:

$v_{m} \equiv v_{B}=v_{A} \cdot \frac{\sin (\psi-\varphi)}{\sin \psi}$

With relation II.24 introduced in formula II.16, velocity $v_{u}$ takes the form II.25.

$\left\{\begin{array}{l}v_{u}=v_{n} \cdot \sin (\psi-\varphi)=v_{m} \cdot \sin \psi \cdot \sin (\psi-\varphi) \\ =v_{A} \cdot \frac{\sin (\psi-\varphi)}{\sin \psi} \cdot \sin \psi \cdot \sin (\psi-\varphi) \\ =v_{A} \cdot \sin ^{2}(\psi-\varphi) \equiv v_{A}^{D}=v_{A} \cdot D\end{array}\right.$

$D^{M}=\sin ^{2}(\psi-\varphi)$

It is obtained from here (from the dynamic kinematics) the expression of the dynamic coefficient $D^{M}$ of the reciprocating piston piston actuated mechanism (relation II.26), noting that it is identical to the expression II.21 where the dynamic coefficient was determined based on the dynamic yield calculation immediate. This checks the uniqueness of the dynamic coefficient for the same actuated mechanism in the same way. To complete this new theory, the dynamic coefficient of the crank shaft driven by the crank shaft (in compressor mode) is to be determined further.

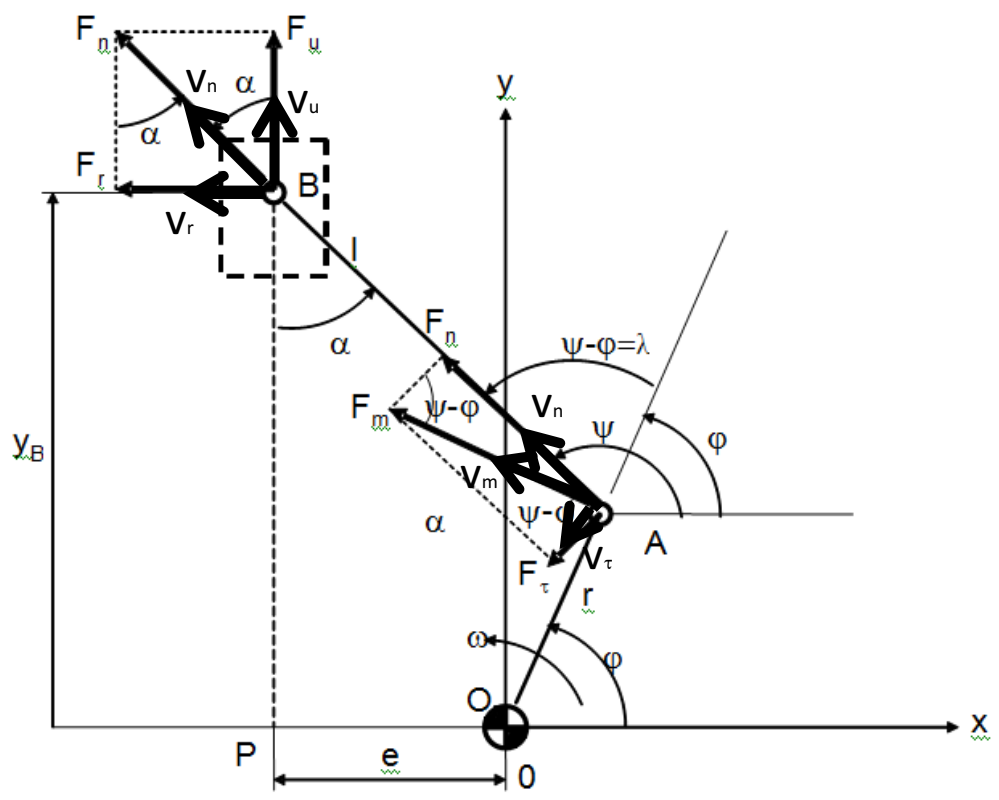

Fig. 30: Dynamic forces and speeds in a piston crankshaft system, when driven from the crank 
Figure 30 shows the transmission of forces aligned with the forces, which occurs in the dynamic cinematic.

The input force $F_{m}$ and the input velocity $v_{m}$ decompose generating the component along the length of the $\operatorname{rod} F_{n}$, respectively, $v_{n}$. Forces are the real forces acting on the mechanism and these cinematic-dynamic velocities are the natural ones that follow the trajectories (directions) imposed by the forces. Generally, they overlap and impose over known kinematic (static) velocities, which are calculated on the basis of the links imposed by the kinematic couple of the mechanism (depending on the kinematic chain). You can write for speeds relations II.27:

$$
\left\{\begin{array}{l}
v_{B}=v_{A} \cdot \frac{\sin (\psi-\varphi)}{\sin \psi} ; \\
v_{B}^{D}=v_{B} \cdot D^{C}=v_{A} \cdot \frac{\sin (\psi-\varphi)}{\sin \psi} \cdot D^{C} \\
v_{u}=v_{n} \cdot \cos \alpha=v_{n} \cdot \sin \psi \\
=v_{m} \cdot \sin \psi \cdot \sin (\psi-\varphi) \\
=v_{A} \cdot \sin \psi \cdot \sin (\psi-\varphi) \\
v_{u}=v_{B}^{D} \Rightarrow v_{A} \cdot \sin \psi \cdot \sin (\psi-\varphi) \\
=v_{A} \cdot \frac{\sin (\psi-\varphi)}{\sin \psi} \cdot D^{C} \\
\Rightarrow D^{C}=\sin ^{2} \psi
\end{array}\right.
$$

For forces, powers and yields, the following relationships are written (II.28-34):

$$
\begin{aligned}
& \left\{\begin{array}{l}
F_{n}=F_{m} \cdot \sin (\psi-\varphi) \\
F_{\tau}=F_{m} \cdot \cos (\psi-\varphi)
\end{array}\right. \\
& \left\{\begin{array}{l}
F_{u}=F_{n} \cdot \cos \alpha=F_{n} \cdot \sin \psi=F_{m} \cdot \sin (\psi-\varphi) \cdot \sin \psi \\
F_{r}=F_{n} \cdot \sin \alpha=-F_{n} \cdot \cos \psi=-F_{m} \cdot \sin (\psi-\varphi) \cdot \cos \psi
\end{array}\right. \\
& \left\{\begin{array}{l}
P_{u}=F_{u} \cdot v_{B}=F_{m} \cdot \sin (\psi-\varphi) \cdot \sin \psi \cdot \\
\frac{r \cdot \omega \cdot \sin (\psi-\varphi)}{\sin \psi}=F_{m} \cdot r \cdot \omega \cdot \sin ^{2}(\psi-\varphi) \\
=F_{m} \cdot v_{A} \cdot \sin ^{2}(\psi-\varphi)
\end{array}\right. \\
& P_{c}=F_{m} \cdot v_{A}=F_{m} \cdot r \cdot \omega \\
& \eta_{i}=\frac{P_{u}}{P_{c}}=\frac{F_{m} \cdot v_{A} \cdot \sin ^{2}(\psi-\varphi)}{F_{m} \cdot v_{A}}=\sin ^{2}(\psi-\varphi) \\
& \left\{\begin{array}{l}
P_{u}^{D}=F_{u} \cdot v_{B}^{D}=F_{m} \cdot \sin (\psi-\varphi) \cdot \sin \psi \cdot v_{A} \cdot \sin \psi \\
\sin (\psi-\varphi)=F_{m} \cdot r \cdot \omega \cdot \sin ^{2}(\psi-\varphi) \cdot \sin ^{2} \psi \\
=F_{m} \cdot v_{A} \cdot \sin ^{2}(\psi-\varphi) \cdot \sin ^{2} \psi
\end{array}\right.
\end{aligned}
$$

\section{Final Discussion}

The first conclusion that can be drawn is that the dynamic momentum dynamics (which is closer to the real mechanism) is less than the normal mechanical efficiency, because the dynamic yield is even the classic mechanical efficiency multiplied by the dynamic coefficient which being subunitarily results that the dynamic yield will be smaller or at most equal to the classic one.

In addition, dynamic performance is the same for crank drive and piston engine actuation and will have the same value regardless of drive type. The dynamic yield is practically uniform, but not all operating modes of the thermal motors are completely dynamic. This makes the Stirling's actual engine power or the two-stroke thermal engine (Lenoir) not much higher than the four-stroke Otto or Diesel engines. The higher the operating speeds, the operating modes become almost completely dynamic.

Today, with high and very high working speeds, fourstroke internal combustion engines achieve comparable performance to those of the Stirling engine or two-stroke engines. The higher the working speeds, the more Stirling or Lenoir benefits.

Although the dynamic mechanical performance (closest to the real) is practically calculated with the same formula regardless of the drive type, the dynamic speeds and accelerations in the couplings differ depending on the drive mode, even for the same coupling.

Thus dynamic velocities (in the dynamic kinematics) of point B are calculated with relations II.35:

$$
\left\{\begin{array}{l}
A-\text { when actionis done from the piston: } \\
D^{M}=\sin ^{2}(\psi-\varphi) ; \eta_{i}=\sin ^{2} \psi ; \text { regim Motor } \\
v_{B}^{D}=v_{B} \cdot D=v_{A} \cdot \frac{\sin (\psi-\varphi)}{\sin \psi} \cdot \sin ^{2}(\psi-\varphi) \\
=v_{A} \cdot \frac{\sin ^{3}(\psi-\varphi)}{\sin \psi} \\
v_{A}^{D}=v_{A} \cdot D=r \cdot \omega \cdot \sin ^{2}(\psi-\varphi) \\
\omega^{D}=\omega \cdot D=\omega \cdot \sin ^{2}(\psi-\varphi) \\
B-w h e n a c t i o n i \operatorname{done} \text { fromthecrank: } \\
D^{C}=\sin ^{2} \psi ; \eta_{i}=\sin ^{2}(\psi-\varphi) ; \text { regim Compressor } \\
v_{B}^{D}=v_{B} \cdot D=v_{A} \cdot \frac{\sin ^{2}(\psi-\varphi)}{\sin \psi} \cdot \sin ^{2} \psi \\
=v_{A} \cdot \sin (\psi-\varphi) \cdot \sin ^{2} \psi \\
v_{A}^{D}=v_{A} \cdot D=r \cdot \omega \cdot \sin ^{2} \psi \\
\omega^{D}=\omega \cdot D=\omega \cdot \sin ^{2} \psi
\end{array}\right.
$$


Even if the dynamic output is uniform, speeds and accelerations are more linear in the crank and sharper (and vibrational) drives during the piston stroke so that four-stroke internal combustion engines are more advantageous at this point view, followed by the twostroke (Lenoir), the last being the Stirling type engines.

Dynamic accelerations are determined with the relationships II.36, in which the dynamic velocity relation (appropriately arranged) is derived to obtain the expression of the dynamic acceleration:

$$
\begin{aligned}
& \left\{\begin{array}{l}
v_{B}^{D}=v_{A} \cdot D \cdot \frac{\sin (\psi-\varphi)}{\sin \psi} \Rightarrow v_{B}^{D} \cdot \sin \psi=v_{A} \cdot D \cdot \sin (\psi-\varphi) \\
\dot{v}_{B}^{D} \cdot \sin \psi+v_{B}^{D} \cdot \cos \psi \cdot \dot{\psi}=v_{A}
\end{array}\right. \\
& \cdot[\dot{D} \cdot \sin (\psi-\varphi)+D \cdot \cos (\psi-\varphi) \cdot(\dot{\psi}-\dot{\varphi})] \\
& \Rightarrow \dot{v}_{B}^{D}=\frac{v_{A} \cdot\left[\begin{array}{l}
\dot{D} \cdot \sin (\psi-\varphi)+D \\
\cdot \cos (\psi-\varphi) \cdot(\dot{\psi}-\dot{\varphi})
\end{array}\right]-v_{B}^{D} \cdot \cos \psi \cdot \dot{\psi}}{\sin \psi} \\
& \Rightarrow a_{B}^{D}=\frac{v_{A}}{\sin ^{2} \psi} \\
& \cdot[\dot{D} \cdot \sin \psi \cdot \sin (\psi-\varphi)+D \cdot \sin \psi \cdot \cos (\psi-\varphi) \cdot(\dot{\psi}-\dot{\varphi}) \\
& -D \cdot \cos \psi \cdot \sin (\psi-\varphi) \cdot \dot{\psi}]=\frac{v_{A}}{\sin ^{2} \psi} \cdot[\dot{D} \cdot \sin \psi \cdot \\
& \sin (\psi-\varphi)+D \cdot \dot{\psi} \cdot \sin \phi-D \cdot \dot{\varphi} \cdot \sin \psi \cdot \cos (\psi-\varphi)] \\
& A-\text { when action is done from the piston: } \\
& D^{M}=\sin ^{2}(\psi-\varphi) ; \dot{D}^{M}=2 \\
& \cdot \sin (\psi-\varphi) \cdot \cos (\psi-\varphi) \cdot(\dot{\psi}-\dot{\varphi}) \\
& B \text { - when action is done from the crank: } \\
& D^{C}=\sin ^{2} \psi ; \quad \dot{D}^{C}=2 \cdot \sin \psi \cdot \cos \psi \cdot \dot{\psi}
\end{aligned}
$$

It is seen that the dynamic disadvantages of thermal motors are in fact a contradiction. The dynamics of their mechanisms is better at crank drive (from the crankshaft), but the driving times (which have a lower dynamic kinematics) are virtually the ones needed, the only ones that produce the power (effectively) and which also generate high returns at the respective thermal engine; on the other hand, however, these engines (motor) produce not only irregular operation with shocks, vibrations and noises on the thermal engine but also generate disadvantageous features. For this reason, the four-stroke Stirling engine and two phases having each active phase show the power and load characteristic at the most disadvantageous speed.

Neither the two-stroke internal combustion engine does not have a very good feature, it also works with vibrations, vibrations and high noises, which can overcome the known beatings of four-stroke diesel engines, the traction presenting shocks (interruptions) even surpass those of the Stirling engines. The Lenoir engine does not make an engine brake, a vehicle equipped with a two-stroke thermal engine is overloaded (the brakes are getting too hot), the safety of the traffic is very low and the comfort of the passengers in the passenger compartment is much diminished.

From this point of view, the Otto or Diesel fourstroke engines are the most advantageous, the first ones actually representing the highest variant. For the Otto engines not to lose the advantage of fuel injection, many years ago it was abandoned to carburation, Otto engines being gradually fueled by the diesel fuel injection (keeps the ignition because the gasoline does not fire itself as it does diesel).

\section{Conclusion}

Only dynamic coefficient of inertia and the influence of kinematic couplings in the system were used in the analyzed sample.

The dynamic coefficient due to elasticity and deformation in the system has not been taken into account since the overwhelming influence of the inertial forces is impacted by additional dynamic changes and also by the kinematic couplings in the system and the elastic deformations do not greatly influence the dynamics of the system in the case of the example remembered.

If a robot was being discussed, things were similar, as in the case of various vehicles and various mechanisms and machines. However, for rigid memory transmissions, elastic deformations are important, which is why they should be considered in such systems.

The presented method is original and has a general character. This method replaces the older method (Petrescu, 2015b) and has a more general and unitary character, the motion equations being concise, unitary, elegant, general.

\section{Acknowledgement}

This text was acknowledged and appreciated by Dr. Veturia CHIROIU Honorific member of Technical Sciences Academy of Romania (ASTR) PhD supervisor in Mechanical Engineering.

\section{Funding Information}

Research contract: 1-Research contract: Contract number 36-5-4D/1986 from 24IV1985, beneficiary CNST RO (Romanian National Center for Science and Technology) Improving dynamic mechanisms.

2-Contract research integration. 19-91-3 from 29.03.1991; Beneficiary: MIS; TOPIC: Research on designing mechanisms with bars, cams and gears, with application in industrial robots.

3-Contract research. GR 69/10.05.2007: NURC in 2762; theme 8: Dynamic analysis of mechanisms and manipulators with bars and gears. 
4-Labor contract, no. 35/22.01.2013, the UPB, "Stand for reading performance parameters of kinematics and dynamic mechanisms, using inductive and incremental encoders, to a Mitsubishi Mechatronic System" "PN-IIIN-CI-2012-1-0389".

All these matters are copyrighted! Copyrights: 394qodGnhhtej, from 17-02-2010 13:42:18; 463vpstuCGsiy, from 20-03-2010 12:45:30; 631sqfsgquutm, from 24-05-2010 16:15:22; 933CrDztEfqow, from 07-01-2011 13:37:52.

\section{Author's Contributions}

All the authors contributed equally to prepare, develop and carry out this manuscript.

\section{Ethics}

This article is original and contains unpublished material. Authors declare that are not ethical issues and no conflict of interest that may arise after the publication of this manuscript.

\section{References}

Ab-Rahman, M.S., H. Guna, MH. Harun, SD. Zan and K. Jumari, 2009. Cost-effective fabrication of self-made $1 \times 12$ polymer optical fiber-based optical splitters for automotive application. Am. J. Eng. Applied Sci., 2: 252-259. DOI: 10.3844/ajeassp.2009.252.259

Abam, F.I., I.U. Ugot and D.I. Igbong, 2012. Performance analysis and components irreversibilities of a $(25$ MW) gas turbine power plant modeled with a spray cooler. Am. J. Eng. Applied Sci., 5: 35-41.

DOI: 10.3844 /ajeassp.2012.35.41

Abdelkrim, H., S.B. Othman, A.K.B. Salem and S.B. Saoud, 2012. Dynamic partial reconfiguration contribution on system on programmable chip architecture for motor drive implementation. Am. J. Eng. Applied Sci., 5: 15-24.

DOI: 10.3844/ajeassp.2012.15.24

Abdullah, M.Z., A. Saat and Z. Hamzah, 2011. Optimization of energy dispersive $\mathrm{x}$-ray fluorescence spectrometer to analyze heavy metals in moss samples. Am. J. Eng. Applied Sci., 4: 355-362. DOI: 10.3844 /ajeassp.2011.355.362

Abdullah, M., A. F.M. Zain, Y. H. Ho and S. Abdullah, 2009. TEC and scintillation study of equatorial ionosphere: A month campaign over sipitang and parit raja stations, Malaysia. Am. J. Eng. Applied Sci., 2: 44-49. DOI: 10.3844/ajeassp.2009.44.49

Abdullah, H. and S.A. Halim, 2009. Electrical and magnetoresistive studies $\mathrm{Nd}$ doped on $\mathrm{La}-\mathrm{Ba}-\mathrm{Mn}-\mathrm{O}_{3}$ manganites for low-field sensor application. Am. J. Eng. Applied Sci., 2: 297-303.

DOI: 10.3844/ajeassp.2009.297.303
Abouobaida, H., 2016. Robust and efficient controller to design a standalone source supplied DC and AC load powered by photovoltaic generator. Am. J. Eng. Applied Sci., 9: 894-901.

DOI: 10.3844 /ajeassp.2016.894.901

Abu-Ein, S., 2009. Numerical and analytical study of exhaust gases flow in porous media with applications to diesel particulate filters. Am. J. Eng. Applied Sci., 2: 70-75.

DOI: 10.3844/ajeassp.2009.70.75

Abu-Lebdeh, M., G. Pérez-de León, S.A. Hamoush, R.D. Seals and V.E. Lamberti, 2016. Gas atomization of molten metal: Part II. Applications. Am. J. Eng. Applied Sci., 9: 334-349.

DOI: 10.3844/ajeassp.2016.334.349

Agarwala, S., 2016. A perspective on 3D bioprinting technology: Present and future. Am. J. Eng. Applied Sci., 9: 985-990.

DOI: 10.3844/ajeassp.2016.985.990

Ahmed, M., R. Khan, M. Billah and S. Farhana, 2010. A novel navigation algorithm for hexagonal hexapod robot. Am. J. Eng. Applied Sci., 3: 320-327.

DOI: 10.3844 /ajeassp.2010.320.327

Ahmed, M.K., H. Haque and H. Rahman, 2016. An approach to develop a dynamic job shop scheduling by fuzzy rule-based system and comparative study with the traditional priority rules. Am. J. Eng. Applied Sci., 9: 202-212.

DOI: 10.3844/ajeassp.2016.202.212

Akhesmeh, S., N. Pourmahmoud and H. Sedgi, 2008. Numerical study of the temperature separation in the ranque-hilsch vortex tube. Am. J. Eng. Applied Sci., 1: 181-187. DOI: 10.3844/ajeassp.2008.181.187

Al-Abbas, I.K., 2009. Reduced order models of a current source inverter induction motor drive. Am. J. Eng. Applied Sci., 2: 39-43.

DOI: 10.3844 /ajeassp.2009.39.43

Al-Hasan and A.S. Al-Ghamdi, 2016. Energy balance for a diesel engine operates on a pure biodiesel, diesel fuel and biodiesel-diesel blends. Am. J. Eng. Applied Sci., 9: 458-465.

DOI: 10.3844/ajeassp.2016.458.465

Al Smadi, T.A., 2011. Low cost smart sensor design. Am. J. Eng. Applied Sci., 4: 162-168. DOI: 10.3844 /ajeassp.2011.162.168

Al Qadi, A.N.S., M.B.A. ALhasanat, A. AL Dahamsheh and S. AL Zaiydneen, 2016a. Using of box-benken method to predict the compressive strength of selfcompacting concrete containing Wadi Musa bentonite, Jordan. Am. J. Eng. Applied Sci., 9: 406411. DOI: 10.3844/ajeassp.2016.406.411

Al Qadi, A.N.S., M.B.A. Alhasanat and M. Haddad, 2016b. Effect of crumb rubber as coarse and fine aggregates on the properties of asphalt concrete. Am. J. Eng. Applied Sci., 9: 558-564. DOI: 10.3844/ajeassp.2016.558.564 
Aleksic, S. and A. Lovric, 2011. Energy consumption and environmental implications of wired access networks. Am. J. Eng. Applied Sci., 4: 531-539. DOI: 10.3844/ajeassp.2011.531.539

Alhasanat, M.B., A.N. Al Qadi, O.A. Al Khashman and A. Dahamsheh, 2016. Scanning electron microscopic evaluation of self-compacting concrete spalling at elevated temperatures. Am. J. Eng. Applied Sci., 9: 119-127.

DOI: $10.3844 /$ ajeassp.2016.119.127

Ali, K.S. and JL. Shumaker, 2013. Hardware in the loop simulator for multi-agent unmanned aerial vehicles environment. Am. J. Eng. Applied Sci., 6: 172-177. DOI: 10.3844/ajeassp.2013.172.177

Ali, G.A.M., O. Fouad and S.A. Makhlouf, 2016. Electrical properties of cobalt oxide/silica nanocomposites obtained by sol-gel technique. Am. J. Eng. Applied Sci., 9: 12-16.

DOI: 10.3844/ajeassp.2016.12.16

Al-Nasra, M. Daoudb and T.M. Abu-Lebdeh, 2015. The use of the super absorbent polymer as water blocker in concrete structures. Am. J. Eng. Applied Sci., 8: 659-665. DOI: 10.3844/ajeassp.2015.659.665

Alwetaishi, M.S., 2016. Impact of building function on thermal comfort: A review paper. Am. J. Eng. Applied Sci., 9: 928-945.

DOI: 10.3844/ajeassp.2016.928.945

Aly, W.M. and M.S. Abuelnasr, 2010. Electronic design automation using object oriented electronics. Am. J. Eng. Applied Sci., 3: 121-127.

DOI: $10.3844 /$ ajeassp.2010.121.127

Amani, N., 2016. Design and implementation of optimum management system using cost evaluation and financial analysis for prevention of building failure. Am. J. Eng. Applied Sci., 9: 281-296. DOI: 10.3844/ajeassp.2016.281.296

Amer, S., S. Hamoush and T.M. Abu-Lebdeh, 2015. Experimental evaluation of the raking energy in damping system of steel stud partition walls. Am. J. Eng. Applied Sci., 8: 666-677.

DOI: 10.3844/ajeassp.2015.666.677

Anizan, S., K. Yusri, C.S. Leong, N. Amin and S. Zaidi et al., 2011. Effects of the contact resistivity variations of the screen-printed silicon solar cell. Am. J. Eng. Applied Sci., 4: 328-331. DOI: 10.3844/ajeassp.2011.328.331

sAntonescu, P. and F. Petrescu, 1985. An analytical method of synthesis of cam mechanism and flat stick. Proceedings of the 4th International Symposium on Theory and Practice of Mechanisms, (TPM' 89), Bucharest.

Antonescu, P. and F. Petrescu, 1989. Contributions to kinetoplast dynamic analysis of distribution mechanisms. Bucharest.
Antonescu, P., M. Oprean and F. Petrescu, 1985a. Contributions to the synthesis of oscillating cam mechanism and oscillating flat stick. Proceedings of the 4th International Symposium on Theory and Practice of Mechanisms, (TPM' 85), Bucharest.

Antonescu, P., M. Oprean and F. Petrescu, 1985b. At the projection of the oscillate cams, there are mechanisms and distribution variables. Proceedings of the 5th Conference of Engines, Automobiles, Tractors and Agricultural Machines, (TAM' 58), IMotors and Cars, Brasov.

Antonescu, P., M. Oprean and F. Petrescu, 1986. Projection of the profile of the rotating camshaft acting on the oscillating plate with disengagement. Proceedings of the 3rd National Computer-aided Design Symposium in the field of Mechanisms and Machine Parts, (MMP' 86), Brasov.

Antonescu, P., M. Oprean and F. Petrescu, 1987. Dynamic analysis of the cam distribution mechanisms. Proceedings of the 7th National Symposium on Industrial Robots and Space Mechanisms, (RSM' 87), Bucharest.

Antonescu, P., M. Oprean and F. Petrescu, 1988. Analytical synthesis of Kurz profile, rotating the flat cam. Mach, Build. Rev.

Antonescu, P., F. Petrescu and O. Antonescu, 1994. Contributions to the synthesis of the rotating cam mechanism and the tip of the balancing tip. Brasov.

Antonescu, P., F. Petrescu and D. Antonescu, 1997. Geometrical synthesis of the rotary cam and balance tappet mechanism. Bucharest, 3: 23-23.

Antonescu, P., F. Petrescu and O. Antonescu, 2000a. Contributions to the synthesis of the rotary disc-cam profile. Proceedings of the 8th International Conference on the Theory of Machines and Mechanisms, (TMM' 00), Liberec, Czech Republic, pp: 51-56.

Antonescu, P., F. Petrescu and O. Antonescu, 2000b. Synthesis of the rotary cam profile with balance follower. Proceedings of the 8th Symposium on Mechanisms and Mechanical Transmissions, (MMT'00), Timişoara, pp: 39-44.

Antonescu, P., F. Petrescu and O. Antonescu, 2001. Contributions to the synthesis of mechanisms with rotary disc-cam. Proceedings of the 8th IFToMM International Symposium on Theory of Machines and Mechanisms, (TMM' 01), Bucharest, ROMANIA, pp: 31-36.

Ascione, F., N. Bianco, R.F. De Masi, F. de Rossi and C. De Stasio et al., 2016. Energy audit of health care facilities: dynamic simulation of energy performances and energy-oriented refurbishment of system and equipment for microclimatic control. Am. J. Eng. Applied Sci., 9: 814-834. DOI: 10.3844/ajeassp.2016.814.834 
Augustine, A., R.D. Prakash, R. Xavier and M.C. Parassery, 2016. Review of signal processing techniques for detection of power quality events. Am. J. Eng. Applied Sci., 9: 364-370. DOI: 10.3844/ajeassp.2016.364.370

Aversa, R., R.V.V. Petrescu, A. Apicella and F.I.T. Petrescu, 2017a. Nano-diamond hybrid materials for structural biomedical application. Am. J. Biochem. Biotechnol., 13: 34-41. DOI: 10.3844/ajbbsp.2017.34.41

Aversa, R., R.V. Petrescu, B. Akash, R.B. Bucinell and J.M. Corchado et al., 2017b. Kinematics and forces to a new model forging manipulator. Am. J. Applied Sci., 14: 60-80. DOI: 10.3844/ajassp.2017.60.80

Aversa, R., R.V. Petrescu, A. Apicella, F.I.T. Petrescu and J.K. Calautit et al., 2017c. Something about the $\mathrm{V}$ engines design. Am. J. Applied Sci., 14: 34-52. DOI: 10.3844/ajassp.2017.34.52

Aversa, R., D. Parcesepe, R.V.V. Petrescu, F. Berto and G. Chen et al., 2017d. Process ability of bulk metallic glasses. Am. J. Applied Sci., 14: 294-301. DOI: 10.3844/ajassp.2017.294.301

Aversa, R., R.V.V. Petrescu, B. Akash, R.B. Bucinell and J.M. Corchado et al., 2017e. Something about the balancing of thermal motors. Am. J. Eng. Applied Sci., 10: 200.217. DOI: 10.3844/ajeassp.2017.200.217

Aversa, R., F.I.T. Petrescu, R.V. Petrescu and A. Apicella, 2016a. Biomimetic FEA bone modeling for customized hybrid biological prostheses development. Am. J. Applied Sci., 13: 1060-1067. DOI: 10.3844/ajassp.2016.1060.1067

Aversa, R., D. Parcesepe, R.V. Petrescu, G. Chen and F.I.T. Petrescu et al., 2016b. Glassy amorphous metal injection molded induced morphological defects. Am. J. Applied Sci., 13: 1476-1482.

DOI: 10.3844/ajassp.2016.1476.1482

Aversa, R., R.V. Petrescu, F.I.T. Petrescu and A. Apicella, 2016c. Smart-factory: Optimization and process control of composite centrifuged pipes. Am. J. Applied Sci., 13: 1330-1341.

DOI: 10.3844/ajassp.2016.1330.1341

Aversa, R., F. Tamburrino, R.V. Petrescu, F.I.T. Petrescu and M. Artur et al., 2016d. Biomechanically inspired shape memory effect machines driven by muscle like acting NiTi alloys. Am. J. Applied Sci., 13: 1264-1271. DOI: 10.3844/ajassp.2016.1264.1271

Aversa, R., E.M. Buzea, R.V. Petrescu, A. Apicella and M. Neacsa et al., 2016e. Present a mechatronic system having able to determine the concentration of carotenoids. Am. J. Eng. Applied Sci., 9: 1106-1111. DOI: 10.3844/ajeassp.2016.1106.1111

Aversa, R., R.V. Petrescu, R. Sorrentino, F.I.T. Petrescu and A. Apicella, 2016f. Hybrid ceramo-polymeric nanocomposite for biomimetic scaffolds design and preparation. Am. J. Eng. Applied Sci., 9: 1096-1105. DOI: 10.3844/ajeassp.2016.1096.1105
Aversa, R., V. Perrotta, R.V. Petrescu, C. Misiano and F.I.T. Petrescu et al., 2016g. From structural colors to super-hydrophobicity and achromatic transparent protective coatings: Ion plating plasma assisted $\mathrm{TiO}_{2}$ and $\mathrm{SiO}_{2}$ nano-film deposition. Am. J. Eng. Applied Sci., 9: 1037-1045. DOI: 10.3844 /ajeassp.2016.1037.1045

Aversa, R., R.V. Petrescu, F.I.T. Petrescu and A. Apicella, 2016h. Biomimetic and evolutionary design driven innovation in sustainable products development. Am. J. Eng. Applied Sci., 9: 10271036. DOI: 10.3844/ajeassp.2016.1027.1036

Aversa, R., R.V. Petrescu, A. Apicella and F.I.T. Petrescu, 2016i. Mitochondria are naturally micro robots - a review. Am. J. Eng. Applied Sci., 9: 9911002. DOI: 10.3844/ajeassp.2016.991.1002

Aversa, R., R.V. Petrescu, A. Apicella and F.I.T. Petrescu, 2016j. We are addicted to vitamins $C$ and E-A review. Am. J. Eng. Applied Sci., 9: 10031018. DOI: 10.3844/ajeassp.2016.1003.1018

Aversa, R., R.V. Petrescu, A. Apicella and F.I.T. Petrescu, 2016k. Physiologic human fluids and swelling behavior of hydrophilic biocompatible hybrid ceramopolymeric materials. Am. J. Eng. Applied Sci., 9: 962972. DOI: 10.3844/ajeassp.2016.962.972

Aversa, R., R.V. Petrescu, A. Apicella and F.I.T. Petrescu, 20161. One can slow down the aging through antioxidants. Am. J. Eng. Applied Sci., 9: 1112-1126. DOI: 10.3844/ajeassp.2016.1112.1126

Aversa, R., R.V. Petrescu, A. Apicella and F.I.T. Petrescu, 2016m. About homeopathy or $\ll$ Similia Similibus Curentur $\gg$. Am. J. Eng. Applied Sci., 9: 1164-1172. DOI: 10.3844/ajeassp.2016.1164.1172

Aversa, R., R.V. Petrescu, A. Apicella and F.I.T. Petrescu, 2016n. The basic elements of life's. Am. J. Eng. Applied Sci., 9: 1189-1197.

DOI: 10.3844/ajeassp.2016.1189.1197

Aversa, R., F.I.T. Petrescu, R.V. Petrescu and A. Apicella, 2016o. Flexible stem trabecular prostheses. Am. J. Eng. Applied Sci., 9: 1213-1221. DOI: 10.3844/ajeassp.2016.1213.122

Babayemi, A.K., 2016. Thermodynamics, non-linear isotherms, statistical modeling and optimization of phosphorus adsorption from wastewater. Am. J. Eng. Applied Sci., 9: 1019-1026.

DOI: 10.3844 /ajeassp.2016.1019.1026

Bakar, R.A., M.K. Mohammed and M.M. Rahman, 2009. Numerical study on the performance characteristics of hydrogen fueled port injection internal combustion engine. Am. J. Eng. Applied Sci., 2: 407-415. DOI: 10.3844/ajeassp.2009.407.415

Barone, G., A. Buonomano, C. Forzano and A. Palombo, 2016. WLHP systems in commercial buildings: A case study analysis based on a dynamic simulation approach. Am. J. Eng. Applied Sci., 9: 659-668. DOI: 10.3844/ajeassp.2016.659.668 
Bedon, C., 2016. Review on the use of FRP composites for facades and building skins. Am. J. Eng. Applied Sci., 9: 713-723.

DOI: 10.3844 /ajeassp.2016.713.723

Bedon, C. and C. Amadio, 2016. A unified approach for the shear buckling design of structural glass walls with non-ideal restraints. Am. J. Eng. Applied Sci., 9: 64-78. DOI: 10.3844/ajeassp.2016.64.78

Bedon, C. and C. Louter, 2016. Finite-element numerical simulation of the bending performance of posttensioned structural glass beams with adhesively bonded CFRP tendons. Am. J. Eng. Applied Sci., 9: 680-691. DOI: 10.3844/ajeassp.2016.680.691

Bier, H. and S. Mostafavi, 2015. Structural optimization for materially informed design to robotic production processes. Am. J. Eng. Applied Sci., 8: 549-555. DOI: 10.3844/ajeassp.2015.549.555

Bolonkin, A., 2009a. Femtotechnology: Nuclear matter with fantastic properties. Am. J. Eng. Applied Sci., 2: 501-514. DOI: 10.3844/ajeassp.2009.501.514

Bolonkin, A., 2009b. Converting of matter to nuclear energy by ab-generator. Am. J. Eng. Applied Sci., 2: 683-693. DOI: 10.3844/ajeassp.2009.683.693

Boucetta, A., 2008. Vector control of a variable reluctance machine stator and rotor discs imbricates. Am. J. Eng. Applied Sci., 1: 260-265.

DOI: 10.3844/ajeassp.2008.260.265

Bourahla, N. and A. Blakeborough, 2015. Similitude distortion compensation for a small scale model of a knee braced steel frame. Am. J. Eng. Applied Sci., 8: 481-488. DOI: 10.3844/ajeassp.2015.481.488

Bucinell, R.B., 2016. Stochastic model for variable amplitude fatigue induced delamination growth in graphite/epoxy laminates. Am. J. Eng. Applied Sci., 9: 635-646. DOI: 10.3844/ajeassp.2016.635.646

Budak, S., Z. Xiao, B. Johnson, J. Cole and M. Drabo et al., 2016. Highly-efficient advanced thermoelectric devices from different multilayer thin films. Am. J. Eng. Applied Sci., 9: 356-363.

DOI: $10.3844 /$ ajeassp.2016.356.363

Buonomano, A., F. Calise and M. Vicidomini, 2016a. A novel prototype of a small-scale solar power plant: Dynamic simulation and thermoeconomic analysis. Am. J. Eng. Applied Sci., 9: 770-788.

DOI: 10.3844/ajeassp.2016.770.788

Buonomano, A., F. Calise, M.D. d'Accadia, R. Vanoli and M. Vicidomini, 2016b. Simulation and experimental analysis of a demonstrative solar heating and cooling plant installed in Naples (Italy). Am. J. Eng. Applied Sci., 9: 798-813.

DOI: 10.3844/ajeassp.2016.798.813

Cao, W., H. Ding, Z. Bin and C. Ziming, 2013. New structural representation and digital-analysis platform for symmetrical parallel mechanisms. Int. J. Adv. Robotic Sys. DOI: 10.5772/56380
Calise, F., M.D. dâ' Accadia, L. Libertini, E. Quiriti and M. Vicidomini, 2016b. Dynamic simulation and optimum operation strategy of a trigeneration system serving a hospital. Am. J. Eng. Applied Sci., 9: 854-867. DOI: 10.3844/ajeassp.2016.854.867

Campo, T., M. Cotto, F. Marquez, E. Elizalde and C. Morant, 2016. Graphene synthesis by plasmaenhanced CVD growth with ethanol. Am. J. Eng. Applied Sci., 9: 574-583. DOI: 10.3844 /ajeassp.2016.574.583

Cardu, M., P. Oreste and T. Cicala, 2009. Analysis of the tunnel boring machine advancement on the BolognaFlorence railway link. Am. J. Eng. Applied Sci., 2: 416-420. DOI: 10.3844/ajeassp.2009.416.420

Casadei, D., 2015. Bayesian statistical inference for number counting experiments. Am. J. Eng. Applied Sci., 8: 730-735. DOI: 10.3844 ajeassp.2015.730.735

Calise, F., M.D. dâ' Accadia, L. Libertini, E. Quiriti and M. Vicidomini, 2016b. Dynamic simulation and optimum operation strategy of a trigeneration system serving a hospital. Am. J. Eng. Applied Sci., 9: 854-867. DOI: 10.3844/ajeassp.2016.854.867

Campo, T., M. Cotto, F. Marquez, E. Elizalde and C. Morant, 2016. Graphene synthesis by plasmaenhanced CVD growth with ethanol. Am. J. Eng. Applied Sci., 9: 574-583. DOI: 10.3844 /ajeassp.2016.574.583

Cardu, M., P. Oreste and T. Cicala, 2009. Analysis of the tunnel boring machine advancement on the BolognaFlorence railway link. Am. J. Eng. Applied Sci., 2: 416-420. DOI: 10.3844/ajeassp.2009.416.420

Casadei, D., 2015. Bayesian statistical inference for number counting experiments. Am. J. Eng. Applied Sci., 8: 730-735. DOI: 10.3844/ajeassp.2015.730.735

Comanescu, A., 2010. Bazele Modelarii Mecanismelor. 1st Edn., E. Politeh, Press, Bucureşti, pp: 274.

Darabi, A., S.A. Soleamani and A. Hassannia, 2008. Fuzzy based digital automatic voltage regulator of a synchronous generator with unbalanced loads. Am. J. Eng. Applied Sci., 1: 280-286. DOI: 10.3844/ajeassp.2008.280.286

Daud, H., N. Yahya, A.A. Aziz and M.F. Jusoh, 2008. Development of wireless electric concept powering electrical appliances. Am. J. Eng. Applied Sci., 1: 12-15. DOI: 10.3844/ajeassp.2008.12.15

Demetriou, D., N. Nikitas and K.D. Tsavdaridis, 2015. Semi active tuned mass dampers of buildings: A simple control option. Am. J. Eng. Applied Sci., 8: 620-632. DOI: 10.3844/ajeassp.2015.620.632

Dixit, S. and S. Pal, 2015. Synthesis and characterization of ink (Carbon)-perovskite/polyaniline ternary composite electrode for sodium chloride separation. Am. J. Eng. Applied Sci., 8: 527-537. DOI: 10.3844/ajeassp.2015.527.537 
Djalel, D., M. Mourad and H. Labar, 2013. New approach of electromagnetic fields of the lightning discharge. Am. J. Eng. Applied Sci., 6: 369-383. DOI: 10.3844/ajeassp.2013.369.383

Dong, H., N. Giakoumidis, N. Figueroa and N. Mavridis, 2013. Approaching behaviour monitor and vibration indication in developing a General Moving Object Alarm System (GMOAS). Int. J. Adv. Robotic Sys. DOI: $10.5772 / 56586$

Ebrahim, N.A., S. Ahmed, S.H.A. Rashid and Z. Taha, 2012. Technology use in the virtual R\&D teams. Am. J. Eng. Applied Sci., 5: 9-14. DOI: 10.3844/ajeassp.2012.9.14

El-Labban, H.F., M. Abdelaziz and E.R.I. Mahmoud, 2013. Modification of carbon steel by laser surface melting: Part I: Effect of laser beam travelling speed on microstructural features and surface hardness. Am. J. Eng. Applied Sci., 6: 352-359. DOI: 10.3844/ajeassp.2013.352.359

Elliott, A., S. AlSalihi, A.L. Merriman and M.M. Basti, 2016. Infiltration of nanoparticles into porous binder jet printed parts. Am. J. Eng. Applied Sci., 9: 128133. DOI: 10.3844/ajeassp.2016.128.133

Elmeddahi, Y., H. Mahmoudi, A. Issaadi, M.F.A. Goosen and R. Ragab, 2016b. Evaluating the effects of climate change and variability on water resources: A case study of the Cheliff Basin in Algeria. Am. J. Eng. Applied Sci., 9: 835-845. DOI: 10.3844/ajeassp.2016.835.845

El-Tous, Y., 2008. Pitch angle control of variable speed wind turbine. Am. J. Eng. Applied Sci., 1: 118-120. DOI: 10.3844/ajeassp.2008.118.120

Faizal, A., S. Mulyono, R. Yendra and A. Fudholi, 2016. Design Maximum Power Point Tracking (MPPT) on photovoltaic panels using fuzzy logic method. Am. J. Eng. Applied Sci., 9: 789-797.

DOI: 10.3844/ajeassp.2016.789.797

Farahani, A.S., N.M. Adam and M.K.A. Ariffin, 2010. Simulation of airflow and aerodynamic forces acting on a rotating turbine ventilator. Am. J. Eng. Applied Sci., 3: 159-170.

DOI: $10.3844 /$ ajeassp.2010.159.170

Farokhi, E. and M. Gordini, 2015. Investigating the parameters influencing the behavior of knee braced steel structures. Am. J. Eng. Applied Sci., 8: 567574. DOI: 10.3844/ajeassp.2015.567.574

Fathallah, A.Z.M. and R.A. Bakar, 2009. Prediction studies for the performance of a single cylinder high speed spark ignition linier engine with spring mechanism as return cycle. Am. J. Eng. Applied Sci., 2: 713-720. DOI: 10.3844/ajeassp.2009.713.720

Fen, Y.W., W.M.M. Yunus, M.M. Moksin, Z.A. Talib and N.A. Yusof, 2011. Optical properties of crosslinked chitosan thin film with glutaraldehyde using surface plasmon resonance technique. Am. J. Eng. Applied Sci., 4: 61-65.

DOI: 10.3844/ajeassp.2011.61.65
Feraga, C.E., A. Moussaoui, A. Bouldjedri and A. Yousfi, 2009. Robust position controller for a permanent magnet synchronous actuator. Am. J. Eng. Applied Sci., 2: 388-392. DOI: 10.3844/ajeassp.2009.388.392

Franklin, D.J., 1930. Ingenious Mechanisms for Designers and Inventors. 1st Edn., Industrial Press Publisher.

Fu, Y.F., J. Gong, H. Huang, Y.J. Liu and D. Zhu et al., 2015. Parameters optimization of adaptive cashew shelling cutter based on BP neural network and genetic algorithm. Am. J. Eng. Applied Sci., 8: 648658. DOI: 10.3844/ajeassp.2015.648.658

Ge, L. and X. Xu, 2015. A scheme design of cloud + end technology in demand side management. Am. J. Eng. Applied Sci., 8: 736-747.

DOI: 10.3844 /ajeassp.2015.736.747

Gupta, P., A. Gupta and A. Asati, 2015. Ultra low power MUX based compressors for wallace and dadda multipliers in sub-threshold regime. Am. J. Eng. Applied Sci., 8: 702-716.

DOI: 10.3844 /ajeassp.2015.702.716

Gusti, A.P. and Semin, 2016. The effect of vessel speed on fuel consumption and exhaust gas emissions. Am. J. Eng. Applied Sci., 9: 1046-1053. DOI: 10.3844/ajeassp.2016.1046.1053

Hassan, M., H. Mahjoub and M. Obed, 2012. Voicebased control of a DC servo motor. Am. J. Eng. Applied Sci., 5: 89-92.

DOI: 10.3844/ajeassp.2012.89.92

Hasan, S. and M.H. El-Naas, 2016. Optimization of a combined approach for the treatment of carbide slurry and capture of $\mathrm{CO}_{2}$. Am. J. Eng. Applied Sci., 9: 449-457. DOI: 10.3844/ajeassp.2016.449.457

Helmy, A.K. and G.S. El-Taweel, 2010. Neural network change detection model for satellite images using textural and spectral characteristics. Am. J. Eng. Applied Sci., 3: 604-610. DOI: 10.3844 /ajeassp.2010.604.610

Hirun, W., 2016. Evaluation of interregional freight generation modelling methods by using nationwide commodity flow survey data. Am. J. Eng. Applied Sci., 9: 625-634. DOI: 10.3844/ajeassp.2016.625.634

Ho, C.Y.F., B.W.K. Ling, S.G. Blasi, Z.W. Chi and W.C. Siu, 2011. Single step optimal block matched motion estimation with motion vectors having arbitrary pixel precisions. Am. J. Eng. Applied Sci., 4: 448-460. DOI: 10.3844/ajeassp.2011.448.460

Huang, B., S.H. Masood, M. Nikzad, P.R. Venugopal and A. Arivazhagan, 2016. Dynamic mechanical properties of fused deposition modelling processed polyphenylsulfone material. Am. J. Eng. Applied Sci., 9: 1-11. DOI: 10.3844/ajeassp.2016.1.11

He, B., Z. Wang, Q. Li, H. Xie and R. Shen, 2013. An analytic method for the kinematics and dynamics of a multiple-backbone continuum robot. IJARS. DOI: $10.5772 / 54051$ 
Idarwazeh, S., 2011. Inverse discrete Fourier transformdiscrete Fourier transform techniques for generating and receiving spectrally efficient frequency division multiplexing signals. Am. J. Eng. Applied Sci., 4: 598-606. DOI: 10.3844/ajeassp.2011.598.606

Iqbal, 2016. An overview of Energy Loss Reduction (ELR) software used in Pakistan by WAPDA for calculating transformer overloading, line losses and energy losses. Am. J. Eng. Applied Sci., 9: 442-448. DOI: 10.3844/ajeassp.2016.442.448

Ismail, M.I.S., Y. Okamoto, A. Okada and Y. Uno, 2011. Experimental investigation on micro-welding of thin stainless steel sheet by fiber laser. Am. J. Eng. Applied Sci., 4: 314-320. DOI: 10.3844/ajeassp.2011.314.320

Jaber, A.A. and R. Bicker, 2016. Industrial robot fault detection based on statistical control chart. Am. J. Eng. Applied Sci., 9: 251-263.

DOI: 10.3844/ajeassp.2016.251.263

Jafari, N., A. Alsadoon, C.P. Withana, A. Beg and A. Elchouemi, 2016. Designing a comprehensive security framework for smartphones and mobile devices. Am. J. Eng. Applied Sci., 9: 724-734.

DOI: 10.3844/ajeassp.2016.724.734

Jalil, M.I.A. and J. Sampe, 2013. Experimental investigation of thermoelectric generator modules with different technique of cooling system. Am. J. Eng. Applied Sci., 6: 1-7.

DOI: 10.3844 /ajeassp.2013.1.7

Jaoude, A.A. and K. El-Tawil, 2013. Analytic and nonlinear prognostic for vehicle suspension systems. Am. J. Eng. Applied Sci., 6: 42-56. DOI: 10.3844 ajeassp.2013.42.56

Jarahi, H., 2016. Probabilistic seismic hazard deaggregation for Karaj City (Iran). Am. J. Eng. Applied Sci., 9: 520-529. DOI: $10.3844 /$ ajeassp.2016.520.529

Jarahi, H. and S. Seifilaleh, 2016. Rock fall hazard zonation in Haraz Highway. Am. J. Eng. Applied Sci., 9: 371-379.

DOI: 10.3844/ajeassp.2016.371.379

Jauhari, K., A. Widodo and I. Haryanto, 2016. Identification of a machine tool spindle critical frequency through modal and imbalance response analysis. Am. J. Eng. Applied Sci., 9: 213-221.

DOI: 10.3844 /ajeassp.2016.213.221

Jiang, J., Q. Chen and S. Nimbalkar, 2016. Field data based method for predicting long-term settlements. Am. J. Eng. Applied Sci., 9: 466-476. DOI: 10.3844/ajeassp.2016.466.476

Kaewnai, S. and S. Wongwises, 2011. Improvement of the runner design of Francis turbine using computational fluid dynamics. Am. J. Eng. Applied Sci., 4: 540-547.

DOI: $10.3844 /$ ajeassp.2011.540.547
Khalifa, A.H.N., A.H. Jabbar and J.A. Muhsin, 2015. Effect of exhaust gas temperature on the performance of automobile adsorption airconditioner. Am. J. Eng. Applied Sci., 8: 575-581. DOI: 10.3844/ajeassp.2015.575.581

Khalil, R., 2015. Credibility of 3D volume computation using GIS for pit excavation and roadway constructions. Am. J. Eng. Applied Sci., 8: 434-442. DOI: 10.3844/ajeassp.2015.434.442

Kamble, V.G. and N. Kumar, 2016. Fabrication and tensile property analysis of polymer matrix composites of graphite and silicon carbide as fillers. Am. J. Eng. Applied Sci., 9: 17-30. DOI: 10.3844/ajeassp.2016.17.30

Kazakov, V.V., V.I. Yusupov, V.N. Bagratashvili, A.I. Pavlikov and V.A. Kamensky, 2016. Control of bubble formation at the optical fiber tip by analyzing ultrasound acoustic waves. Am. J. Eng. Applied Sci., 9: 921-927. DOI: 10.3844/ajeassp.2016.921.927

Kechiche, O.B.H.B., H.B.A. Sethom, H. Sammoud and I.S. Belkhodja, 2011. Optimized high-frequency signal injection based permanent magnet synchronous motor rotor position estimation applied to washing machines. Am. J. Eng. Applied Sci., 4: 390-399. DOI: 10.3844/ajeassp.2011.390.399

Kuli, I., T.M. Abu-Lebdeh, E.H. Fini and S.A. Hamoush, 2016. The use of nano-silica for improving mechanical properties of hardened cement paste. Am. J. Eng. Applied Sci., 9: 146-154. DOI: 10.3844/ajeassp.2016.146.154

Kumar, N.D., R.D. Ravali and PR. Srirekha, 2015. Design and realization of pre-amplifier and filters for on-board radar system. Am. J. Eng. Applied Sci., 8: 689-701. DOI: 10.3844/ajeassp.2015.689.701

Kunanoppadon, J., 2010. Thermal efficiency of a combined turbocharger set with gasoline engine. Am. J. Eng. Applied Sci., 3: 342-349. DOI: 10.3844 /ajeassp.2010.342.349

Kwon, S., Y. Tani, H. Okubo and T. Shimomura, 2010. Fixed-star tracking attitude control of spacecraft using single-gimbal control moment gyros. Am. J. Eng. Applied Sci., 3: 49-55.

DOI: 10.3844 /ajeassp.2010.49.55

Lamarre, A., E.H. Fini and T.M. Abu-Lebdeh, 2016. Investigating effects of water conditioning on the adhesion properties of crack sealant. Am. J. Eng. Applied Sci., 9: 178-186. DOI: 10.3844/ajeassp.2016.178.186

Lee, B.J., 2013. Geometrical derivation of differential kinematics to calibrate model parameters of flexible manipulator. Int. J. Adv. Robotic Syst. DOI: $10.5772 / 55592$

Li, R., B. Zhang, S. Xiu, H. Wang and L. Wang et al., 2015. Characterization of solid residues obtained from supercritical ethanol liquefaction of swine manure. Am. J. Eng. Applied Sci., 8: 465- 470. DOI: $10.3844 /$ ajeassp.2015.465.470 
Lin, W., B. Li, X. Yang and D. Zhang, 2013. Modelling and control of inverse dynamics for a 5-DOF parallel kinematic polishing machine. Int. J. Adv. Robotic Sys. DOI: 10.5772/54966

Liu, H., W. Zhou, X. Lai and S. Zhu, 2013. An efficient inverse kinematic algorithm for a PUMA560structured robot manipulator. IJARS. DOI: $10.5772 / 56403$

Lubis, Z., A.N. Abdalla, Mortaza and R. Ghon, 2009. Mathematical modeling of the three phase induction motor couple to DC motor in hybrid electric vehicle. Am. J. Eng. Applied Sci., 2: 708-712. DOI: 10.3844/ajeassp.2009.708.712

Madani, D.A. and A. Dababneh, 2016. Rapid entire body assessment: A literature review. Am. J. Eng. Applied Sci., 9: 107-118. DOI: 10.3844/ajeassp.2016.107.118

Malomar, G.E.B., A. Gueye, C. Mbow, V.B. Traore and A.C. Beye, 2016. Numerical study of natural convection in a square porous cavity thermally modulated on both side walls. Am. J. Eng. Applied Sci., 9: 591-598.

DOI: 10.3844 /ajeassp.2016.591.598

Mansour, M.A.A., 2016. Developing an anthropometric database for Saudi students and comparing Saudi dimensions relative to Turkish and Iranian peoples. Am. J. Eng. Applied Sci., 9: 547-557. DOI: 10.3844/ajeassp.2016.547.557

Maraveas, C., Z.C. Fasoulakis and K.D. Tsavdaridis, 2015. A review of human induced vibrations on footbridges. Am. J. Eng. Applied Sci., 8: 422-433. DOI: 10.3844/ajeassp.2015.422.433

Marghany, M. and M. Hashim, 2009. Robust of doppler centroid for mapping sea surface current by using radar satellite data. Am. J. Eng. Applied Sci., 2: 781-788. DOI: 10.3844/ajeassp.2009.781.788

Martins, F.R., A.R. Gonçalves and E.B. Pereira, 2016. Observational study of wind shear in northeastern Brazil. Am. J. Eng. Applied Sci., 9: 484-504. DOI: 10.3844/ajeassp.2016.484.504

Marzuki, M.A.L.B., M.H. Abd Halim and A.R.N. Mohamed, 2015. Determination of natural frequencies through modal and harmonic analysis of space frame race car chassis based on ANSYS. Am. J. Eng. Applied Sci., 8: 538-548.

DOI: $10.3844 /$ ajeassp. 2015.538 .548

Mavukkandy, M.O., S. Chakraborty, T. Abbasi and S.A. Abbasi, 2016. A clean-green synthesis of platinum nanoparticles utilizing a pernicious weed lantana (Lantana Camara). Am. J. Eng. Applied Sci., 9: 84-90. DOI: 10.3844/ajeassp.2016.84.90

Minghini, F., N. Tullini and F. Ascione, 2016. Updating Italian design guide CNR DT-205/2007 in view of recent research findings: Requirements for pultruded FRP profiles. Am. J. Eng. Applied Sci., 9: 702-712. DOI: 10.3844/ajeassp.2016.702.712
Moezi, N., D. Dideban and A. Ketabi, 2008. A novel integrated SET based inverter for nano power electronic applications. Am. J. Eng. Applied Sci., 1: 219-222. DOI: 10.3844/ajeassp.2008.219.222

Mohamed, M.A., A.Y. Tuama, M. Makhtar, M.K. Awang and M. Mamat, 2016. The effect of RSA exponential key growth on the multi-core computational resource. Am. J. Eng. Applied Sci., 9: 1054-1061. DOI: 10.3844/ajeassp.2016.1054.1061

Mohan, K.S.R., P. Jayabalan and A. Rajaraman, 2012. Properties of fly ash based coconut fiber composite. Am. J. Eng. Applied Sci., 5: 29-34. DOI: 10.3844 /ajeassp.2012.29.34

Mohseni, E. and K.D. Tsavdaridis, 2016. Effect of nanoalumina on pore structure and durability of class $f$ fly ash self-compacting mortar. Am. J. Eng. Applied Sci., 9: 323-333. DOI: 10.3844 /ajeassp.2016.323.333

Momani, M.A., T.A. Al Smadi, FM. Al Taweel and K.A. Ghaidan, 2011. GPS ionospheric total electron content and scintillation measurements during the October 2003 magnetic storm. Am. J. Eng. Applied Sci., 4: 301-306. DOI: 10.3844/ajeassp.2011.301.306

Momta, P.S., J.O. Omoboh and M.I. Odigi, 2015. Sedimentology and depositional environment of D2 sand in part of greater ughelli depobelt, onshore Niger Delta, Nigeria. Am. J. Eng. Applied Sci., 8: 556-566. DOI: 10.3844/ajeassp.2015.556.566

Mondal, R., S. Sahoo and C.S. Rout, 2016. Mixed nickel cobalt manganese oxide nanorods for supercapacitor application. Am. J. Eng. Applied Sci., 9: 540-546. DOI: 10.3844/ajeassp.2016.540.546

Montgomery, J., T.M. Abu-Lebdeh, S.A. Hamoush and M. Picornell, 2016. Effect of nano-silica on the compressive strength of harden cement paste at different stages of hydration. Am. J. Eng. Applied Sci., 9: 166-177. DOI: 10.3844/ajeassp.2016.166.177

Moretti, M.L., 2015. Seismic design of masonry and reinforced concrete infilled frames: A comprehensive overview. Am. J. Eng. Applied Sci., 8: 748-766. DOI: 10.3844/ajeassp.2015.748.766

Morse, A., M.M. Mansfield, R.M. Alley, H.A. Kerr and R.B. Bucinell, 2016b. Traction enhancing products affect maximum torque at the shoe-floor interface: A potential increased risk of ACL injury. Am. J. Eng. Applied Sci., 9: 889-893.

DOI: 10.3844 /ajeassp.2016.889.893

Moubarek, T. and A. Gharsallah, 2016. A six-port reflectometer calibration using Wilkinson power divider. Am. J. Eng. Applied Sci., 9: 274-280. DOI: 10.3844/ajeassp.2016.274.280

Nabilou, A., 2016a. Effect of parameters of selection and replacement drilling bits based on geo-mechanical factors: (Case study: Gas and oil reservoir in the Southwest of Iran). Am. J. Eng. Applied Sci., 9: 380-395. DOI: 10.3844/ajeassp.2016.380.395 
Nabilou, A., 2016b. Study of the parameters of Steam Assisted Gravity Drainage (SAGD) method for enhanced oil recovery in a heavy oil fractured carbonate reservoir. Am. J. Eng. Applied Sci., 9: 647-658. DOI: 10.3844/ajeassp.2016.647.658

Nachiengtai, T., W. Chim-Oye, S. Teachavorasinskun and W. Sa-Ngiamvibool, 2008. Identification of shear band using elastic shear wave propagation. Am. J. Eng. Applied Sci., 1: 188-191.

DOI: 10.3844 /ajeassp.2008.188.191

Nahas, R. and S.P. Kozaitis, 2014. Metric for the fusion of synthetic and real imagery from multimodal sensors. Am. J. Eng. Applied Sci., 7: 355-362. DOI: 10.3844/ajeassp.2014.355.362

Nandhakumar, S., V. Selladurai and S. Sekar, 2009. Numerical investigation of an industrial robot arm control problem using haar wavelet series. Am. J. Eng. Applied Sci., 2: 584-589.

DOI: 10.3844/ajeassp.2009.584.589

Ng, K.C., M.Z. Yusoff, K. Munisamy, H. Hasini and N.H. Shuaib, 2008. Time-marching method for computations of high-speed compressible flow on structured and unstructured grid. Am. J. Eng. Applied Sci., 1: 89-94.

DOI: 10.3844/ajeassp.2008.89.94

Obaiys, S.J., Z. Abbas, N.M.A. Nik Long, A.F. Ahmad and A. Ahmedov et al., 2016. On the general solution of first-kind hypersingular integral equations. Am. J. Eng. Applied Sci., 9: 195-201. DOI: 10.3844/ajeassp.2016.195.201

Odeh, S., R. Faqeh, L. Abu Eid and N. Shamasneh, 2009. Vision-based obstacle avoidance of mobile robot using quantized spatial model. Am. J. Eng. Applied Sci., 2: 611-619. DOI: 10.3844/ajeassp.2009.611.619

Ong, A.T., A. Mustapha, Z.B. Ibrahim, S. Ramli and B.C. Eong, 2015. Real-time automatic inspection system for the classification of PCB flux defects. Am. J. Eng. Applied Sci., 8: 504-518. DOI: 10.3844/ajeassp.2015.504.518

Opafunso, Z.O., I.I. Ozigis and I.A. Adetunde, 2009. Pneumatic and hydraulic systems in coal fluidized bed combustor. Am. J. Eng. Applied Sci., 2: 88-95. DOI: 10.3844 /ajeassp.2009.88.95

Orlando, N. and E. Benvenuti, 2016. Advanced XFEM simulation of pull-out and debonding of steel bars and FRP-reinforcements in concrete beams. Am. J. Eng. Applied Sci., 9: 746-754.

DOI: 10.3844/ajeassp.2016.746.754

Pannirselvam, N., P.N. Raghunath and K. Suguna, 2008. Neural network for performance of glass fibre reinforced polymer plated RC beams. Am. J. Eng. Applied Sci., 1: 82-88.

DOI: $10.3844 /$ ajeassp.2008.82.88
Pattanasethanon, S., 2010. The solar tracking system by using digital solar position sensor. Am. J. Eng. Applied Sci., 3: 678-682.

DOI: 10.3844 /ajeassp.2010.678.682

Pérez-de León, G., V.E. Lamberti, R.D. Seals, T.M. Abu-Lebdeh and S.A. Hamoush, 2016. Gas atomization of molten metal: Part I. Numerical modeling conception. Am. J. Eng. Applied Sci., 9: 303-322. DOI: 10.3844/ajeassp.2016.303.322

Padula, F. and V. Perdereau, 2013. An on-line path planner for industrial manipulators. Int. J. Adv. Robotic Sys. DOI: 10.5772/55063

Perumaal, S. and N. Jawahar, 2013. Automated trajectory planner of industrial robot for pick-andplace task. IJARS. DOI: 10.5772/53940

Petrescu, F. and R. Petrescu, 1995a. Contributions to optimization of the polynomial motion laws of the stick from the internal combustion engine distribution mechanism. Bucharest, 1: 249-256.

Petrescu, F. and R. Petrescu, 1995b. Contributions to the synthesis of internal combustion engine distribution mechanisms. Bucharest, 1: 257-264.

Petrescu, F. and R. Petrescu, 1997a. Dynamics of cam mechanisms (exemplified on the classic distribution mechanism). Bucharest, 3: 353-358.

Petrescu, F. and R. Petrescu, 1997b. Contributions to the synthesis of the distribution mechanisms of internal combustion engines with a Cartesian coordinate method. Bucharest, 3: 359-364.

Petrescu, F. and R. Petrescu, 1997c. Contributions to maximizing polynomial laws for the active stroke of the distribution mechanism from internal combustion engines. Bucharest, 3: 365-370.

Petrescu, F. and R. Petrescu, 2000a. Synthesis of distribution mechanisms by the rectangular (Cartesian) coordinate method. Proceedings of the 8th National Conference on International Participation, (CIP' 00), Craiova, Romania, pp: 297-302.

Petrescu, F. and R. Petrescu, 2000b. The design (synthesis) of cams using the polar coordinate method (triangle method). Proceedings of the 8th National Conference on International Participation, (CIP' 00), Craiova, Romania, pp: 291-296.

Petrescu, F. and R. Petrescu, 2002a. Motion laws for cams. Proceedings of the International Computer Assisted Design, National Symposium with Participation, (SNP' 02), Braşov, pp: 321-326.

Petrescu, F. and R. Petrescu, 2002b. Camshaft dynamics elements. Proceedings of the International Computer Assisted Design, National Participation Symposium, (SNP' 02), Braşov, pp: 327-332.

Petrescu, F. and R. Petrescu, 2003. Some elements regarding the improvement of the engine design. Proceedings of the National Symposium, Descriptive Geometry, Technical Graphics and Design, (GTD' 03), Braşov, pp: 353-358. 
Petrescu, F. and R. Petrescu, 2005a. The cam design for a better efficiency. Proceedings of the International Conference on Engineering Graphics and Design, (EGD’ 05), Bucharest, pp: 245-248.

Petrescu, F. and R. Petrescu, 2005b. Contributions at the dynamics of cams. Proceedings of the 9th IFToMM International Symposium on Theory of Machines and Mechanisms, (TMM' 05), Bucharest, Romania, pp: 123-128.

Petrescu, F. and R. Petrescu, 2005c. Determining the dynamic efficiency of cams. Proceedings of the 9th IFToMM International Symposium on Theory of Machines and Mechanisms, (TMM' 05), Bucharest, Romania, pp: 129-134.

Petrescu, F. and R. Petrescu, 2005d. An original internal combustion engine. Proceedings of the 9th IFToMM International Symposium on Theory of Machines and Mechanisms, (TMM' 05), Bucharest, Romania, pp: 135-140.

Petrescu, F. and R. Petrescu, 2005e. Determining the mechanical efficiency of Otto engine's mechanism. Proceedings of the 9th IFToMM International Symposium on Theory of Machines and Mechanisms, (TMM 05), Bucharest, Romania, pp: 141-146.

Petrescu, F.I. and R.V. Petrescu, 2011a. Mechanical Systems, Serial and Parallel (Romanian). 1st Edn., LULU Publisher, London, UK, pp: 124.

Petrescu, F.I.T. and RV. Petrescu, 2011b. Trenuri Planetare. 1st Edn., Createspace Independent Pub., ISBN-13: 978-1468030419, pp: 104.

Petrescu, F.I. and R.V. Petrescu, 2012a. Kinematics of the planar quadrilateral mechanism. ENGEVISTA, 14: 345-348.

Petrescu, F.I. and R.V. Petrescu, 2012b. MecatronicaSisteme Seriale si Paralele. 1st Edn., Create Space Publisher, USA, pp: 128.

Petrescu, F.I. and R.V. Petrescu, 2013a. Cinematics of the 3R dyad. ENGEVISTA, 15: 118-124.

Petrescu, F.I.T. and R.V. Petrescu, 2013b. Forces and efficiency of cams. Int. Rev. Mech. Eng., 7: 507-511.

Petrescu, F.I.T. and R.V. Petrescu, 2013c. Cams with high efficiency. Int. Rev. Mech. Eng., 7: 599-606.

Petrescu, F.I.T. and R.V. Petrescu, 2013d. An algorithm for setting the dynamic parameters of the classic distribution mechanism. Int. Rev. Modell. Simulat., 6: 1637-1641.

Petrescu, F.I.T. and R.V. Petrescu, 2013e. Dynamic synthesis of the rotary cam and translated tappet with roll. Int. Rev. Modell. Simulat., 6: 600-607.

Petrescu, F.I.T. and R.V. Petrescu, 2014a. Parallel moving mechanical systems. Independent J. Manage. Product., 5: 564-580.

Petrescu, F.I.T. and R.V. Petrescu, 2014b. Cam gears dynamics in the classic distribution. Independent $\mathrm{J}$. Manage. Product., 5: 166-185.
Petrescu, F.I.T. and R.V. Petrescu, 2014c. Highefficiency gears synthesis by avoid the interferences. Independent J. Manage. Product., 5: 275-298.

Petrescu, F.I.T. and R.V. Petrescu, 2014d. Gear design. J. ENGEVISTA, 16: 313-328.

Petrescu, F.I.T. and R.V. Petrescu, 2014e. Kinetostatic of the $3 \mathrm{R}$ dyad (or $2 \mathrm{R}$ module). J. ENGEVISTA, 16: 314-321.

Petrescu, F.I.T. and R.V. Petrescu, 2014f. Balancing Otto engines. Int. Rev. Mech. Eng., 8: 473-480.

Petrescu, F.I.T. and R.V. Petrescu, 2014g. Machine equations to the classical distribution. Int. Rev. Mech. Eng., 8: 309-316.

Petrescu, F.I.T. and R.V. Petrescu, 2014h. Forces of internal combustion heat engines. Int. Rev. Modell. Simulat., 7: 206-212.

Petrescu, F.I.T. and R.V. Petrescu, 2014i. Determination of the yield of internal combustion thermal engines. Int. Rev. Mech. Eng., 8: 62-67.

Petrescu, F.I.T. and R.V. Petrescu, 2015a. Forces at the main mechanism of a railbound forging manipulator. Independent J. Manage. Product., 6: 904-921.

Petrescu, F.I.T. and R.V. Petrescu, 2015b. Kinematics at the main mechanism of a railbound forging manipulator. Independent J. Manage. Product., 6: 711-729.

Petrescu, F.I.T. and R.V. Petrescu, 2015c. Machine motion equations. Independent J. Manage. Product., 6: 773-802.

Petrescu F.I.T. and R.V. Petrescu, 2015d. Presenting a railbound forging manipulator. Applied Mech. Mater., 762: 219-224.

Petrescu, F.I.T. and R.V. Petrescu, 2015e. About the anthropomorphic robots. J. ENGEVISTA, 17: 1-15.

Petrescu, F.I. and R.V. Petrescu, 2016a. Parallel moving mechanical systems kinematics. ENGEVISTA, 18: 455-491.

Petrescu, F.I. and R.V. Petrescu, 2016b. Direct and inverse kinematics to the anthropomorphic robots. ENGEVISTA, 18: 109-124.

Petrescu, F.I. and R.V. Petrescu, 2016c. Dynamic cinematic to a structure 2R. Revista Geintec-Gestao Inovacao E Tecnol., 6: 3143-3154.

Petrescu, FIT. and R.V. Petrescu, 2016d. An Otto engine dynamic model. Independent J. Manage. Product., 7: 038-048.

Petrescu, R.V., R. Aversa, A. Apicella and F.I. Petrescu, 2016. Future medicine services robotics. Am. J. Eng. Applied Sci., 9: 1062-1087.

DOI: 10.3844/ajeassp.2016.1062.1087

Petrescu, F.I., B. Grecu, A. Comanescu and R.V. Petrescu, 2009. Some mechanical design elements. Proceeding of the International Conference on Computational Mechanics and Virtual Engineering, (MVE' 09), Braşov, pp: 520-525. 
Petrescu, F.I.T., 2011. Teoria Mecanismelor si a Masinilor: Curs Si Aplicatii. 1st Edn., CreateSpace Independent Publishing Platform. ISBN-10: 1468015826. pp: 432.

Petrescu, F.I.T., 2015a. Geometrical synthesis of the distribution mechanisms. Am. J. Eng. Applied Sci., 8: 63-81. DOI: 10.3844/ajeassp.2015.63.81

Petrescu, F.I.T., 2015b. Machine motion equations at the internal combustion heat engines. Am. J. Eng. Applied Sci., 8: 127-137. DOI: 10.3844/ajeassp.2015.127.137

Petrescu, F.I.T., A. Apicella, A. Raffaella, R.V. Petrescu and J.K. Calautit et al., 2016. Something about the mechanical moment of Inertia. Am. J. Applied Sci., 13: $1085-1090$.

DOI: 10.3844/ajassp.2016.1085.1090

Petrescu, R.V., R. Aversa, B. Akash, R. Bucinell and J. Corchado et al., 2017a. Yield at thermal engines internal combustion. Am. J. Eng. Applied Sci., 10: 243-251. DOI: 10.3844/ajeassp.2017.243.251

Petrescu, R.V., R. Aversa, B. Akash, B. Ronald and J. Corchado et al., 2017b. Velocities and accelerations at the 3R mechatronic systems. Am. J. Eng. Applied Sci., 10: 252-263.

DOI: 10.3844/ajeassp.2017.252.263

Petrescu, R.V., R. Aversa, B. Akash, R. Bucinell and J. Corchado et al., 2017c. Anthropomorphic solid structures n-r kinematics. Am. J. Eng. Applied Sci., 10: 279-291. DOI: 10.3844/ajeassp.2017.279.291

Petrescu, R.V., R. Aversa, B. Akash, R. Bucinell and J. Corchado et al., 2017d. Inverse kinematics at the anthropomorphic robots, by a trigonometric method. Am. J. Eng. Applied Sci., 10: 394-411. DOI: 10.3844/ajeassp.2017.394.411

Petrescu, R.V., R. Aversa, B. Akash, R. Bucinell and J. Corchado et al., 2017e. Forces at internal combustion engines. Am. J. Eng. Applied Sci., 10: 382-393. DOI: 10.3844/ajeassp.2017.382.393

Petrescu, R.V., R. Aversa, B. Akash, R. Bucinell and J. Corchado et al., 2017f. Gears-Part I. Am. J. Eng. Applied Sci., 10: 457-472. DOI: 10.3844/ajeassp.2017.457.472

Petrescu, R.V., R. Aversa, B. Akash, R. Bucinell and J. Corchado et al., 2017g. Gears-part II. Am. J. Eng. Applied Sci., 10: 473-483.

DOI: 10.3844 /ajeassp.2017.473.483

Petrescu, R.V., R. Aversa, B. Akash, R. Bucinell and J. Corchado et al., 2017h. Cam-gears forces, velocities, powers and efficiency. Am. J. Eng. Applied Sci., 10: 491-505.

DOI: 10.3844/ajeassp.2017.491.505

Petrescu, R.V., R. Aversa, B. Akash, R. Bucinell and J. Corchado et al., 2017i. Dynamics of mechanisms with cams illustrated in the classical distribution. Am. J. Eng. Applied Sci., 10: 551-567.

DOI: 10.3844 /ajeassp.2017.551.567
Petrescu, R.V., R. Aversa, B. Akash, R. Bucinell and J. Corchado et al., 2017j. Testing by non-destructive control. Am. J. Eng. Applied Sci., 10: 568-583. DOI: 10.3844 /ajeassp.2017.568.583

Petrescu, R.V., R. Aversa, A. Apicella and F.I.T. Petrescu, 2017k. Transportation engineering. Am. J. Eng. Applied Sci., 10: 685-702. DOI: 10.3844/ajeassp.2017.685.702

Petrescu, R.V., R. Aversa, S. Kozaitis, A. Apicella and F.I.T. Petrescu, 20171. The quality of transport and environmental protection, part I. Am. J. Eng. Applied Sci., 10: 738-755. DOI: 10.3844 /ajeassp.2017.738.755

Petrescu, R.V., R. Aversa, B. Akash, R. Bucinell and J. Corchado et al., $2017 \mathrm{~m}$. Modern propulsions for aerospace-a review. J. Aircraft Spacecraft Technol., 1: 1-8. DOI: 10.3844/jastsp.2017.1.8

Petrescu, R.V., R. Aversa, B. Akash, R. Bucinell and J. Corchado et al., 2017n. Modern propulsions for aerospace-part II. J. Aircraft Spacecraft Technol., 1: 9-17. DOI: $10.3844 /$ jastsp.2017.9.17

Petrescu, R.V., R. Aversa, B. Akash, R. Bucinell and J. Corchado et al., 2017o. History of aviation-a short review. J. Aircraft Spacecraft Technol., 1: 30-49. DOI: 10.3844 jastsp.2017.30.49

Petrescu, R.V., R. Aversa, B. Akash, R. Bucinell and J. Corchado et al., 2017p. Lockheed martin-a short review. J. Aircraft Spacecraft Technol., 1: 50-68. DOI: $10.3844 /$ jastsp.2017.50.68

Petrescu, R.V., R. Aversa, B. Akash, J. Corchado and F. Berto et al., 2017q. Our universe. J. Aircraft Spacecraft Technol., 1: 69-79. DOI: $10.3844 /$ jastsp.2017.69.79

Petrescu, R.V., R. Aversa, B. Akash, J. Corchado and F. Berto et al., 2017r. What is a UFO? J. Aircraft Spacecraft Technol., 1: 80-90. DOI: 10.3844 jastsp.2017.80.90

Petrescu, R.V., R. Aversa, B. Akash, J. Corchado and F. Berto et al., 2017s. About bell helicopter FCX-001 concept aircraft-a short review. J. Aircraft Spacecraft Technol., 1: 91-96.

DOI: 10.3844 jastsp.2017.91.96

Petrescu, R.V., R. Aversa, B. Akash, J. Corchado and F. Berto et al., 2017t. Home at airbus. J. Aircraft Spacecraft Technol., 1: 97-118. DOI: $10.3844 /$ jastsp.2017.97.118

Petrescu, R.V., R. Aversa, B. Akash, J. Corchado and F. Berto et al., 2017u. Airlander. J. Aircraft Spacecraft Technol., 1: 119-148. DOI: 10.3844/jastsp.2017.119.148

Petrescu, R.V., R. Aversa, B. Akash, J. Corchado and F. Berto et al., 2017v. When boeing is dreaming-a review. J. Aircraft Spacecraft Technol., 1: 149-161. DOI: 10.3844/jastsp.2017.149.161 
Petrescu, R.V., R. Aversa, B. Akash, J. Corchado and F. Berto et al., 2017w. About Northrop Grumman. J. Aircraft Spacecraft Technol., 1: 162-185.

DOI: $10.3844 /$ jastsp.2017.162.185

Petrescu, R.V., R. Aversa, B. Akash, J. Corchado and F. Berto et al., 2017x. Some special aircraft. J. Aircraft Spacecraft Technol., 1: 186-203.

DOI: 10.3844/jastsp.2017.186.203

Petrescu, R.V., R. Aversa, B. Akash, J. Corchado and F. Berto et al., 2017y. About helicopters. J. Aircraft Spacecraft Technol., 1: 204-223.

DOI: 10.3844/jastsp.2017.204.223

Petrescu, R.V., R. Aversa, B. Akash, F. Berto and A. Apicella et al., 2017z. The modern flight. J. Aircraft Spacecraft Technol., 1: 224-233.

DOI: $10.3844 /$ jastsp.2017.224.233

Petrescu, R.V., R. Aversa, B. Akash, F. Berto and A. Apicella et al., 2017aa. Sustainable energy for aerospace vessels. J. Aircraft Spacecraft Technol., 1: 234-240. DOI: 10.3844/jastsp.2017.234.240

Petrescu, R.V., R. Aversa, B. Akash, F. Berto and A. Apicella et al., 2017ab. Unmanned helicopters. J. Aircraft Spacecraft Technol., 1: 241-248. DOI: $10.3844 /$ jastsp.2017.241.248

Petrescu, R.V., R. Aversa, B. Akash, F. Berto and A. Apicella et al., 2017ac. Project HARP. J. Aircraft Spacecraft Technol., 1: 249-257. DOI: 10.3844/jastsp.2017.249.257

Petrescu, R.V., R. Aversa, B. Akash, F. Berto and A. Apicella et al., 2017ad. Presentation of Romanian engineers who contributed to the development of global aeronautics-part I. J. Aircraft Spacecraft Technol., 1: 258-271. DOI: 10.3844 /jastsp.2017.258.271

Petrescu, R.V., R. Aversa, B. Akash, F. Berto and A. Apicella et al., 2017ae. A first-class ticket to the planet mars, please. J. Aircraft Spacecraft Technol., 1: 272-281. DOI: 10.3844/jastsp.2017.272.281

Petrescu, R.V., R. Aversa, A. Apicella, M.M. Mirsayar and S. Kozaitis et al., 2018a. NASA started a propeller set on board voyager 1 after 37 years of break. Am. J. Eng. Applied Sci., 11: 66-77. DOI: 10.3844/ajeassp.2018.66.77

Petrescu, R.V., R. Aversa, A. Apicella, M.M. Mirsayar and S. Kozaitis et al., 2018b. There is life on mars? Am. J. Eng. Applied Sci., 11: 78-91.

DOI: 10.3844/ajeassp.2018.78.91

Petrescu, R.V., R. Aversa, A. Apicella and F.I.T. Petrescu, 2018c. Friendly environmental transport. Am. J. Eng. Applied Sci., 11: 154-165. DOI: 10.3844/ajeassp.2018.154.165

Petrescu, R.V., R. Aversa, B. Akash, T.M. Abu-Lebdeh and A. Apicella et al., 2018d. Buses running on gas. Am. J. Eng. Applied Sci., 11: 186-201. DOI: 10.3844 /ajeassp.2018.186.201
Petrescu, R.V., R. Aversa, B. Akash, T.M. Abu-Lebdeh and A. Apicella et al., 2018e. Some aspects of the structure of planar mechanisms. Am. J. Eng. Applied Sci., 11: 245-259.

DOI: 10.3844 /ajeassp.2018.245.259

Petrescu, RV., R. Aversa, T.M. Abu-Lebdeh, A. Apicella and F.I.T. Petrescu, 2018f. The forces of a simple carrier manipulator. Am. J. Eng. Applied Sci., 11: 260-272. DOI: 10.3844/ajeassp.2018.260.272

Petrescu, RV., R. Aversa, T.M. Abu-Lebdeh, A. Apicella and F.I.T. Petrescu, 2018g. The dynamics of the otto engine. Am. J. Eng. Applied Sci., 11: 273-287. DOI: 10.3844 /ajeassp.2018.273.287

Petrescu, RV., R. Aversa, T.M. Abu-Lebdeh, A. Apicella and F.I.T. Petrescu, 2018h. NASA satellites help us to quickly detect forest fires. Am. J. Eng. Applied Sci., 11: 288-296. DOI: 10.3844 /ajeassp.2018.288.296

Petrescu, RV., R. Aversa, T.M. Abu-Lebdeh, A. Apicella and F.I.T. Petrescu, 2018i. Kinematics of a mechanism with a triad. Am. J. Eng. Applied Sci., 11: 297-308. DOI: 10.3844/ajeassp.2018.297.308

Petrescu, R.V., R. Aversa, A. Apicella and F.I.T. Petrescu, 2018j. Romanian engineering "on the wings of the wind". J. Aircraft Spacecraft Technol., 2: 1-18. DOI: $10.3844 /$ jastsp.2018.1.18

Petrescu, R.V., R. Aversa, A. Apicella and F.I.T. Petrescu, 2018k. NASA Data used to discover eighth planet circling distant star. J. Aircraft Spacecraft Technol., 2: 19-30. DOI: $10.3844 /$ jastsp.2018.19.30

Petrescu, R.V., R. Aversa, A. Apicella and F.I.T. Petrescu, 20181. NASA has found the most distant black hole. J. Aircraft Spacecraft Technol., 2: 31-39. DOI: $10.3844 /$ jastsp.2018.31.39

Petrescu, R.V., R. Aversa, A. Apicella and F.I.T. Petrescu, 2018m. Nasa selects concepts for a new mission to titan, the moon of saturn. J. Aircraft Spacecraft Technol., 2: 40-52. DOI: $10.3844 /$ jastsp.2018.40.52

Petrescu, R.V., R. Aversa, A. Apicella and F.I.T. Petrescu, 2018n. NASA sees first in 2018 the direct proof of ozone hole recovery. J. Aircraft Spacecraft Technol., 2: 53-64. DOI: 10.3844/jastsp.2018.53.64

Pisello, A.L., G. Pignatta, C. Piselli, V.L. Castaldo and F. Cotana, 2016. Investigating the dynamic thermal behavior of building envelope in summer conditions by means of in-field continuous monitoring. Am. J. Eng. Applied Sci., 9: 505-519.

DOI: 10.3844/ajeassp.2016.505.519

Pourmahmoud, N., 2008. Rarefied gas flow modeling inside rotating circular cylinder. Am. J. Eng. Applied Sci., 1: 62-65. DOI: 10.3844/ajeassp.2008.62.65 
Pravettoni, M., C.S.P. Lòpez and R.P. Kenny, 2016. Impact of the edges of a backside diffusive reflector on the external quantum efficiency of luminescent solar concentrators: Experimental and computational approach. Am. J. Eng. Applied Sci., 9: 53-63. DOI: 10.3844 /ajeassp.2016.53.63

Qutbodin, K., 2010. Merging autopilot/flight control and navigation-flight management systems. Am. J. Eng. Applied Sci., 3: 629-630.

DOI: 10.3844/ajeassp.2010.629.630

Rajbhandari, S., Z. Ghassemlooy and M. Angelova, 2011. The performance of a dual header pulse interval modulation in the presence of artificial light interferences in an indoor optical wireless communications channel with wavelet denoising. Am. J. Eng. Applied Sci., 4: 513-519. DOI: 10.3844/ajeassp.2011.513.519

Rajput, R.S., S. Pandey and S. Bhadauria, 2016. Correlation of biodiversity of algal genera with special reference to the waste water effluents from industries. Am. J. Eng. Applied Sci., 9: 1127-1133. DOI: 10.3844/ajeassp.2016.1127.1133

Rajupillai, K., S. Palaniammal and K. Bommuraju, 2015. Computational intelligence and application of frame theory in communication systems. Am. J. Eng. Applied Sci., 8: 633-637.

DOI: 10.3844/ajeassp.2015.633.637

Raptis, K.G., G.A. Papadopoulos, T.N. Costopoulos and A.D. Tsolakis, 2011. Experimental study of load sharing in roller-bearing contact by caustics and photoelasticity. Am. J. Eng. Applied Sci., 4: 294300. DOI: 10.3844/ajeassp.2011.294.300

Rama, G., D. Marinkovic and M. Zehn, 2016. Efficient co-rotational 3-node shell element. Am. J. Eng. Applied Sci., 9: 420-431.

DOI: 10.3844/ajeassp.2016.420.431

Rea, P. and E. Ottaviano, 2016. Analysis and mechanical design solutions for sit-to-stand assisting devices. Am. J. Eng. Applied Sci., 9: 1134-1143. DOI: 10.3844/ajeassp.2016.1134.1143

Rhode-Barbarigos, L., V. Charpentier, S. Adriaenssens and O. Baverel, 2015. Dialectic form finding of structurally integrated adaptive structures. Am. J. Eng. Applied Sci., 8: 443-454.

DOI: 10.3844/ajeassp.2015.443.454

Riccio, A., U. Caruso, A. Raimondo and A. Sellitto, 2016a. Robustness of XFEM method for the simulation of cracks propagation in fracture mechanics problems. Am. J. Eng. Applied Sci., 9: 599-610. DOI: 10.3844/ajeassp.2016.599.610

Riccio, A., R. Cristiano and S. Saputo, 2016b. A brief introduction to the bird strike numerical simulation. Am. J. Eng. Applied Sci., 9: 946-950.

DOI: 10.3844 /ajeassp.2016.946.950
Rich, F. and M.A. Badar, 2016. Statistical analysis of auto dilution $\mathrm{Vs}$ manual dilution process in inductively coupled plasma spectrometer tests. Am. J. Eng. Applied Sci., 9: 611-624. DOI: 10.3844 /ajeassp.2016.611.624

Rohit, K. and S. Dixit, 2016. Mechanical properties of waste Biaxially Oriented Polypropylene metallized films (BOPP), LLDPE: LDPE films with sisal fibres. Am. J. Eng. Applied Sci., 9: 913-920. DOI: 10.3844 /ajeassp.2016.913.920

Rulkov, N.F., A.M. Hunt, P.N. Rulkov and A.G. Maksimov, 2016. Quantization of map-based neuronal model for embedded simulations of neurobiological networks in real-time. Am. J. Eng. Applied Sci., 9: 973-984. DOI: 10.3844/ajeassp.2016.973.984

Saikia, A. and N. Karak, 2016. Castor oil based epoxy/clay nanocomposite for advanced applications. Am. J. Eng. Applied Sci., 9: 31-40. DOI: 10.3844/ajeassp.2016.31.40

Sallami, A., N. Zanzouri and M. Ksouri, 2016. Robust diagnosis of a DC motor by bond graph approach. Am. J. Eng. Applied Sci., 9: 432-438. DOI: 10.3844 /ajeassp.2016.432.438

Samantaray, K.S., S. Sahoo and C.S. Rout, 2016. Hydrothermal synthesis of CuWO4-reduced graphene oxide hybrids and supercapacitor application. Am. J. Eng. Applied Sci., 9: 584-590. DOI: 10.3844 /ajeassp.2016.584.590

Santos, F.A. and C. Bedon, 2016. Preliminary experimental and finite-element numerical assessment of the structural performance of SMAreinforced GFRP systems. Am. J. Eng. Applied Sci., 9: 692-701. DOI: 10.3844/ajeassp.2016.692.701

Semin, A.R. Ismail and R.A. Bakar, 2009a. Combustion temperature effect of diesel engine convert to compressed natural gas engine. Am. J. Eng. Applied Sci., 2: 212-216. DOI: 10.3844/ajeassp.2009.212.216

Semin, A.R. Ismail and R.A. Bakar, 2009b. Effect of diesel engine converted to sequential port injection compressed natural gas engine on the cylinder pressure Vs crank angle in variation engine speeds. Am. J. Eng. Applied Sci., 2: 154-159. DOI: 10.3844 /ajeassp.2009.154.159

Semin S., A.R. Ismail and R.A. Bakar, 2009c. Diesel engine convert to port injection $\mathrm{CNG}$ engine using gaseous injector nozzle multi holes geometries improvement: A review. Am. J. Eng. Applied Sci., 2: 268-278. DOI: 10.3844/ajeassp.2009.268.278

Semin and R.A. Bakar, 2008. A technical review of compressed natural gas as an alternative fuel for internal combustion engines. Am. J. Eng. Applied Sci., 1: 302-311.

DOI: 10.3844 /ajeassp.2008.302.311 
Sepúlveda, J.A.M., 2016. Outlook of municipal solid waste in Bogota (Colombia). Am. J. Eng. Applied Sci., 9: 477-483.

DOI: 10.3844/ajeassp.2016.477.483

Serebrennikov, A., D. Serebrennikov and Z. Hakimov, 2016. Polyethylene pipeline bending stresses at an installation. Am. J. Eng. Applied Sci., 9: 350-355. DOI: 10.3844/ajeassp.2016.350.355

Shanmugam, K., 2016. Flow dynamic behavior of fish oil/silver nitrate solution in mini-channel, effect of alkane addition on flow pattern and interfacial tension. Am. J. Eng. Applied Sci., 9: 236-250.

DOI: 10.3844/ajeassp.2016.236.250

Shruti, 2016. Comparison in cover media under stegnography: Digital media by hide and seek approach. Am. J. Eng. Applied Sci., 9: 297-302. DOI: 10.3844/ajeassp.2016.297.302

Stavridou, N., E. Efthymiou and C.C. Baniotopoulos, 2015a. Welded connections of wind turbine towers under fatigue loading: Finite element analysis and comparative study. Am. J. Eng. Applied Sci., 8: 489-503. DOI: 10.3844/ajeassp.2015.489.503

Stavridou, N., E. Efthymiou and C.C. Baniotopoulos, 2015b. Verification of anchoring in foundations of wind turbine towers. Am. J. Eng. Applied Sci., 8: 717-729. DOI: 10.3844/ajeassp.2015.717.729

Suarez, L., T.M. Abu-Lebdeh, M. Picornell and S.A. Hamoush, 2016. Investigating the role of fly ash and silica fume in the cement hydration process. Am. J. Eng. Applied Sci., 9: 134-145.

DOI: 10.3844 /ajeassp.2016.134.145

Syahrullah, O.I. and N. Sinaga, 2016. Optimization and prediction of motorcycle injection system performance with feed-forward back-propagation method Artificial Neural Network (ANN). Am. J. Eng. Applied Sci., 9: 222-235.

DOI: 10.3844/ajeassp.2016.222.235

Sylvester, O., I. Bibobra and O.N. Ogbon, 2015a. Well test and PTA for reservoir characterization of key properties. Am. J. Eng. Applied Sci., 8: 638-647. DOI: 10.3844/ajeassp.2015.638.647

Sylvester, O., I. Bibobra and O. Augustina, 2015b. Report on the evaluation of Ugua J2 and J3 reservoir performance. Am. J. Eng. Applied Sci., 8: 678-688. DOI: 10.3844/ajeassp.2015.678.688

Taher, S.A., R. Hematti and M. Nemati, 2008. Comparison of different control strategies in GAbased optimized UPFC controller in electric power systems. Am. J. Eng. Applied Sci., 1: 45-52.

DOI: 10.3844/ajeassp.2008.45.52

Takeuchi, T., Y. Kinouchi, R. Matsui and T. Ogawa, 2015. Optimal arrangement of energy-dissipating members for seismic retrofitting of truss structures. Am. J. Eng. Applied Sci., 8: 455-464.

DOI: 10.3844/ajeassp.2015.455.464
Theansuwan, W. and K. Triratanasirichai, 2011. The biodiesel production from roast Thai sausage oil by transesterification reaction. Am. J. Eng. Applied Sci., 4: 130-132. DOI: 10.3844 ajeassp.2011.130.132

Thongwan, T., A. Kangrang and S. Homwuttiwong, 2011. An estimation of rainfall using fuzzy setgenetic algorithms model. Am. J. Eng. Applied Sci., 4: 77-81. DOI: 10.3844/ajeassp.2011.77.81

Tourab, W., A. Babouri and M. Nemamcha, 2011. Experimental study of electromagnetic environment in the vicinity of high voltage lines. Am. J. Eng. Applied Sci., 4: 209-213.

DOI: 10.3844 /ajeassp.2011.209.213

Tsolakis, A.D. and K.G. Raptis, 2011. Comparison of maximum gear-tooth operating bending stresses derived from niemann's analytical procedure and the finite element method. Am. J. Eng. Applied Sci., 4: 350-354. DOI: 10.3844/ajeassp.2011.350.354

Vernardos, S.M. and C.J. Gantes, 2015. Cross-section optimization of sandwich-type cylindrical wind turbine towers. Am. J. Eng. Applied Sci., 8: 471-480. DOI: 10.3844/ajeassp.2015.471.480

Wang, L., T. Liu, Y. Zhang and X. Yuan, 2016. A methodology for continuous evaluation of cloud resiliency. Am. J. Eng. Applied Sci., 9: 264-273. DOI: 10.3844/ajeassp.2016.264.273

Wang, L., G. Wang and C.A. Alexander, 2015. Confluences among big data, finite element analysis and high-performance computing. Am. J. Eng. Applied Sci., 8: 767-774.

DOI: 10.3844/ajeassp.2015.767.774

Wang, J. and Y. Yagi, 2016. Fragment-based visual tracking with multiple representations. Am. J. Eng. Applied Sci., 9: 187-194.

DOI: 10.3844 /ajeassp.2016.187.194

Waters, C., S. Ajinola and M. Salih, 2016. Dissolution sintering technique to create porous copper with sodium chloride using polyvinyl alcohol solution through powder metallurgy. Am. J. Eng. Applied Sci. 9: 155-165. DOI: 10.3844/ajeassp.2016.155.165

Wessels, L. and H. Raad, 2016. Recent advances in point of care diagnostic tools: A review. Am. J. Eng. Applied Sci., 9: 1088-1095. DOI: 10.3844/ajeassp.2016.1088.1095

Yang, M.F. and Y. Lin, 2015. Process is unreliable and quantity discounts supply chain integration inventory model. Am. J. Eng. Applied Sci., 8: 602-610. DOI: 10.3844 /ajeassp.2015.602.610

Yeargin, R., R. Ramey and C. Waters, 2016. Porosity analysis in porous brass using dual approaches. Am. J. Eng. Applied Sci., 9: 91-97. DOI: 10.3844/ajeassp.2016.91.97 
You, M., X. Huang, M. Lin, Q. Tong and X. Li et al., 2016. Preparation of $\mathrm{LiCoMnO}_{4}$ assisted by hydrothermal approach and its electrochemical performance. Am. J. Eng. Applied Sci., 9: 396-405. DOI: 10.3844/ajeassp.2016.396.405

Zeferino, R.S., J.A.R. Ramón, E. de Anda Reyes, R.S. González and U. Pal, 2016. Large scale synthesis of $\mathrm{ZnO}$ nanostructures of different morphologies through solvent-free mechanochemical synthesis and their application in photocatalytic dye degradation. Am. J. Eng. Applied Sci., 9: 41-52. DOI: 10.3844/ajeassp.2016.41.52

Zhao, B., 2013. Identification of multi-cracks in the gate rotor shaft based on the wavelet finite element method. Am. J. Eng. Applied Sci., 6: 309-319.

DOI: 10.3844/ajeassp.2013.309.319

Zheng, H. and S. Li, 2016. Fast and robust maximum power point tracking for solar photovoltaic systems. Am. J. Eng. Applied Sci., 9: 755-769.

DOI: 10.3844/ajeassp.2016.755.769

Zotos, I.S. and T.N. Costopoulos, 2009. On the use of rolling element bearings' models in Precision maintenance. Am. J. Eng. Applied Sci., 2: 344-352. DOI: 10.3844/ajeassp.2009.344.352
Zulkifli, R., K. Sopian, S. Abdullah and M.S. Takriff, 2008. Effect of pulsating circular hot air jet frequencies on local and average nusselt number. Am. J. Eng. Applied Sci., 1: 57-61. DOI: 10.3844/ajeassp.2008.57.61

Zulkifli, R., K. Sopian, S. Abdullah and M.S. Takriff, 2009. Experimental study of flow structures of circular pulsating air jet. Am. J. Eng. Applied Sci., 2: 171-175. DOI: 10.3844/ajeassp.2009.171.175

Zurfi, A. and J. Zhang, 2016a. Model identification and wall-plug efficiency measurement of white LED modules. Am. J. Eng. Applied Sci., 9: 412-419. DOI: 10.3844 /ajeassp.2016.412.419

Zurfi, A. and J. Zhang, 2016b. Exploitation of battery energy storage in load frequency control-a literature survey. Am. J. Eng. Applied Sci., 9: 1173-1188. DOI: 10.3844 /ajeassp.2016.1173.1188

\section{Source of Figures:} 2016.

Petrescu, 2011, Petrescu, 2015b and Petrescu et al., 